\title{
Cr(VI) Sorption from Aqueous Solution: A Review
}

\author{
Angelo Fenti ${ }^{1}$, Simeone Chianese ${ }^{1,2}, *(\mathbb{D})$, Pasquale Iovino ${ }^{2,3}\left(\mathbb{D}\right.$, Dino Musmarra ${ }^{1,2} \mathbb{C}$ \\ and Stefano Salvestrini ${ }^{2,3, *(D)}$ \\ 1 Department of Engineering, University of Campania “Luigi Vanvitelli”, Via Roma 29, 81031 Aversa (CE), Italy; \\ angelo.fenti@unicampania.it (A.F.); dino.musmarra@unicampania.it (D.M.) \\ 2 Environmental Technologies, University Spin Off of University of Campania "Luigi Vanvitelli", \\ Department of Environmental, Biological and Pharmaceutical Sciences and Technologies via Vivaldi, 43, \\ 81100 Caserta, Italy; pasquale.iovino@unicampania.it \\ 3 Department of Environmental, Biological and Pharmaceutical Sciences and Technologies, \\ University of Campania “Luigi Vanvitelli”, via Vivaldi 43, 81100 Caserta, Italy \\ * Correspondence: simeone.chianese@unicampania.it (S.C.); stefano.salvestrini@unicampania.it (S.S.)
}

Received: 26 August 2020; Accepted: 15 September 2020; Published: 17 September 2020

\begin{abstract}
Hexavalent chromium (Cr(VI)) in water systems is a major hazard for living organisms, including humans. The most popular technology currently used to remove $\mathrm{Cr}(\mathrm{VI})$ from polluted water is sorption for its effectiveness, ease of use, low cost and environmental friendliness. The electrostatic interactions between chromium species and the sorbent matrix are the main determinants of $\mathrm{Cr}(\mathrm{VI})$ sorption. The $\mathrm{pH}$ plays a central role in the process by affecting chromium speciation and the net charge on sorbent surface. In most cases, $\mathrm{Cr}(\mathrm{VI})$ sorption is an endothermic process whose kinetics is satisfactorily described by the pseudo second-order model. A critical survey of the recent literature, however, reveals that the thermodynamic and kinetic parameters reported for $\mathrm{Cr}(\mathrm{VI})$ sorption are often incorrect and/or erroneously interpreted.
\end{abstract}

Keywords: hexavalent chromium; sorption; sorption isotherm; sorption kinetics; pseudo first order model; pseudo second order model; sorption thermodynamics

\section{Introduction}

Environmental pollution is currently a cause of serious concern worldwide. Anthropogenic activities produce increasing amounts of processing waste and effluents that contain a diversity of pollutants, including harmful heavy metals [1]. Among these, chromium is well known for its mutagenic and carcinogenic effects [2]. Chromium naturally occurs in the earth's crust and water bodies but its level in the environment tends to increase in association with anthropogenic activities such as metallurgy, wood processing, and production of inorganic chemicals, printed circuit boards and dyes [3,4].

Chromium predominantly occurs in the $+3(\mathrm{Cr}(\mathrm{III}))$ and $+6(\mathrm{Cr}(\mathrm{VI}))$ oxidation states. $\mathrm{Cr}(\mathrm{VI})$ is highly soluble in aqueous systems and exhibits higher soil mobility and higher toxicity than $\mathrm{Cr}(\mathrm{III})$ [5]. In fact, the hexavalent form of chromium is highly toxic and carcinogenic, while the trivalent form is innocuous and may even be used as a micronutrient in certain organisms [6]. $\mathrm{Cr}(\mathrm{VI})$ has a high diffusion and dissolution capacity in the tissues [7]. Its compounds can be absorbed by humans through the skin and respiratory system and rapidly diffuse in the body due to their ability to enter the erythrocytes and bind to hemoglobin. Documented harmful effects of $\mathrm{Cr}(\mathrm{VI})$ in humans include lung cancer, respiratory problems, renal failure, weakening of the immune system, skin lesions, genetic damage and infertility [8]. $\mathrm{Cr}(\mathrm{VI})$ species enter the cells across non-specific anionic channels, thanks to structural analogy with sulphate and phosphate ions. $\mathrm{Cr}^{5+}$ complexes, produced by reduction of $\mathrm{Cr}(\mathrm{VI})$ within the cells, may react with endogenous $\mathrm{H}_{2} \mathrm{O}_{2}$ to generate potentially mutagenic $\mathrm{OH}$ radicals [9]. 
Recognizing the multi-faceted harmful effects of $\mathrm{Cr}(\mathrm{VI})$ on living organisms, the US Environmental Protection Agency (US-EPA) has established a maximum level in drinking and surface water of 0.015 and $0.1 \mathrm{mg} \mathrm{L}^{-1}$, respectively [10].

The removal of $\mathrm{Cr}(\mathrm{VI})$ from water is an issue that is drawing increasing attention within the scientific community. Among a diversity of methods tested so far, sorption is the most popular because it is fast, relatively inexpensive and easy to use. Not surprisingly, therefore, a considerable effort has been done for the development of novel sorbents for $\mathrm{Cr}(\mathrm{VI})$ removal since the last century [11-16]. Here we present a critical review of the experimental work performed on $\mathrm{Cr}(\mathrm{VI})$ sorption in the last decade, with emphasis on proposed mechanisms and thermodynamic and kinetic aspects.

\section{Cr(VI) Behavior in Solution and Proposed Sorption Mechanisms: Effect of pH}

Sorption is a general term encompassing a diversity of processes such as adsorption, absorption, ion exchange and surface precipitation, as well as a diversity of mechanisms depending on the physicochemical properties of sorbate and sorbent. Being a surface phenomenon, sorption usually increases with an increase of the surface area of the sorbent [17-19]. Other factors, notably the $\mathrm{pH}$ and the surface charge of the sorbent, may play a leading role in the process $[8,20]$.

$\mathrm{Cr}(\mathrm{VI})$ is present in water in different oxyanionic forms (e.g., $\mathrm{HCrO}_{4}{ }^{-}, \mathrm{CrO}_{4}{ }^{2-}$ and $\mathrm{Cr}_{2} \mathrm{O}_{7}{ }^{2-}$ ) or as undissociated chromic acid, $\mathrm{H}_{2} \mathrm{CrO}_{4}$, the relative abundance of each species being strongly related to the $\mathrm{pH}$. The equilibria that contribute most significantly to $\mathrm{Cr}(\mathrm{VI})$ speciation in water are reported below [21-23]:

$$
\begin{array}{cc}
\mathrm{H}_{2} \mathrm{CrO}_{4} \rightleftarrows \mathrm{H}^{+}+\mathrm{HCrO}_{4}^{-} & \mathrm{K}_{1}=0.37 \\
\mathrm{HCrO}_{4}^{-} \rightleftarrows \mathrm{H}^{+}+\mathrm{CrO}_{4}^{2-} & \mathrm{K}_{2}=3.2 \times 10^{-7} \\
2 \mathrm{HCrO}_{4}^{-} \rightleftarrows \mathrm{Cr}_{2} \mathrm{O}_{7}^{2-}+\mathrm{H}_{2} \mathrm{O} & \mathrm{K}_{3}=35.5
\end{array}
$$

where $K_{1}, K_{2}$ and $K_{3}$ are the equilibrium constants of the three reactions. The first two equilibria are $\mathrm{pH}$-dependent whereas the third only depends on total $\mathrm{Cr}(\mathrm{VI})$ concentration. The effect of $\mathrm{pH}$ and total $\mathrm{Cr}(\mathrm{VI})$ concentration (based on Equations (1)-(3)) on $\mathrm{Cr}(\mathrm{VI})$ species distribution, is shown in Figure 1 in a range of concentrations commonly found in contaminated water systems [24].

As can be seen from Figure $1, \mathrm{HCrO}_{4}{ }^{-}$and $\mathrm{CrO}_{4}{ }^{2-}$ are the most abundant species at acid and basic $\mathrm{pH}$, respectively. Due to the negative net charge of $\mathrm{Cr}(\mathrm{VI})$ oxyanions, $\mathrm{Cr}(\mathrm{VI})$ sorption is expected to involve electrostatic interactions or anion exchange with positively-charged sorbent sites $[6,24,25]$. The uptake of $\mathrm{Cr}(\mathrm{VI})$ should be favored by a $\mathrm{pH}$ below the point of zero charge, which would impart the sorbent a net positive charge [20]. Chromium sorption should be less efficient under alkaline conditions than in acidic medium, not only because of electrostatic repulsion between chromium oxyanions and negatively-charged sites on sorbent surface but also because of competition with $\mathrm{OH}^{-}$ for sorbent sites.

In line with the analysis above, most papers on $\mathrm{Cr}(\mathrm{VI})$ report a decreasing sorption capacity with increasing pH. A typical trend of sorption capacity vs. $\mathrm{pH}$ is shown in Figure $2[20,25,26]$. 

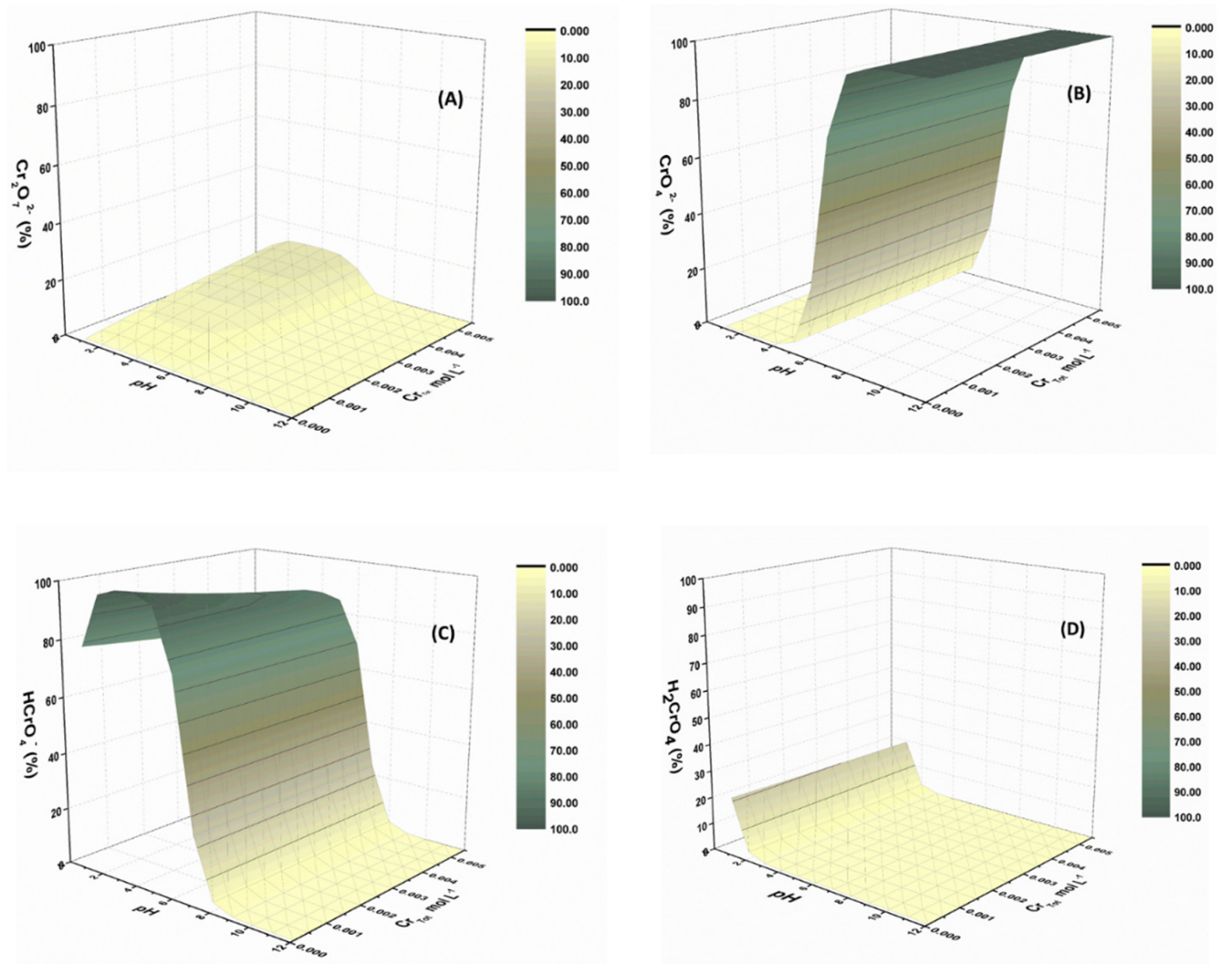

Figure 1. $\mathrm{Cr}(\mathrm{VI})$ species distribution $(\%)$ as a function of $\mathrm{pH}$ and total $\mathrm{Cr}(\mathrm{VI})$ concentration: $(\mathbf{A}) \mathrm{Cr}_{2} \mathrm{O}_{7}{ }^{2-}$; (B) $\mathrm{CrO}_{4}^{2-}$; (C) $\mathrm{H}_{2} \mathrm{CrO}_{4}$; (D) $\mathrm{HCrO}_{4}{ }^{-}$.

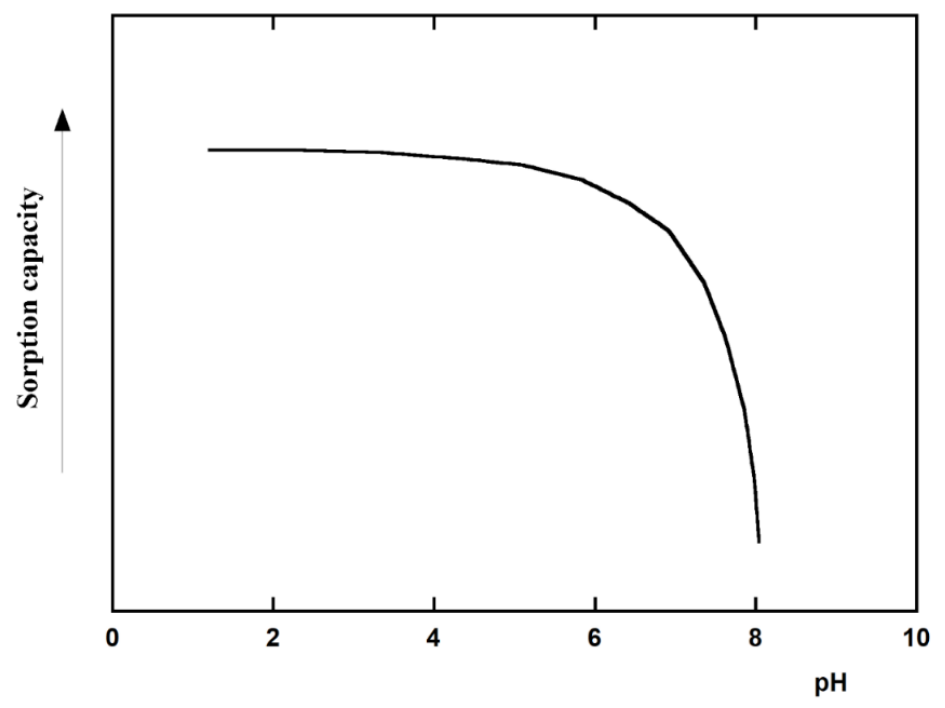

Figure 2. Typical decreasing trend of $\mathrm{Cr}(\mathrm{VI})$ sorption capacity vs. $\mathrm{pH}$.

Shi et al. [20], for example, investigated the sorption performance of the anion-exchange resins D301, D314 and D354 for Cr(VI). The authors ascribed the observed sorption behavior with varying $\mathrm{pH}$ (similar to that shown in Figure 2), to an anion exchange process between $\mathrm{Cr}$ species and $\mathrm{OH}^{-}$ anions associated to $-\mathrm{N}\left(\mathrm{CH}_{3}\right)_{2}$ functional groups of the resins, according to the following reactions:

$$
\begin{aligned}
& \mathrm{R}-\mathrm{OH}+\mathrm{HCrO}_{4}^{-} \rightleftharpoons \mathrm{R}-\mathrm{HCrO}_{4}+\mathrm{OH}^{-} \\
& 2 \mathrm{R}-\mathrm{OH}+\mathrm{CrO}_{4}^{2-} \rightleftharpoons \mathrm{R}_{2}-\mathrm{CrO}_{4}+2 \mathrm{OH}^{-}
\end{aligned}
$$




$$
\begin{gathered}
2 \mathrm{R}-\mathrm{OH}+2 \mathrm{HCrO}_{4}^{-} \rightleftharpoons \mathrm{R}_{2}-\mathrm{Cr}_{2} \mathrm{O}_{7}+2 \mathrm{OH}^{-}+\mathrm{H}_{2} \mathrm{O} \\
2 \mathrm{R}-\mathrm{OH}+\mathrm{Cr}_{2} \mathrm{O}_{7}^{2-} \rightleftharpoons \mathrm{R}_{2}-\mathrm{Cr}_{2} \mathrm{O}_{7}+2 \mathrm{OH}^{-}
\end{gathered}
$$

where $\mathrm{R}$ is the resins' matrix.

The authors reported that the amount of $\mathrm{Cr}(\mathrm{VI})$ sorbed in acidic condition was double than in alkali condition. An obvious explanation is that in acidic condition the exchanged $\mathrm{OH}$ - reacts with $\mathrm{H}^{+}$, thus promoting the forward reactions in Equations (4)-(7). At alkaline $\mathrm{pH}$ values, the sorption of $\mathrm{Cr}(\mathrm{VI})$ is hampered by competition between $\mathrm{CrO}_{4}{ }^{2-}$ and $\mathrm{OH}^{-}$for binding sites. At high $\mathrm{pH}$ (i.e., in excess of $\mathrm{OH}^{-}$), this competitive effect leads to a drastic reduction of $\mathrm{Cr}(\mathrm{VI})$ uptake (Figure 2).

Kyzas et al. [25] investigated the sorption of $\mathrm{Cr}(\mathrm{VI})$ on chitosan derivatives cross-linked and grafted with amino and carboxyl groups. The authors observed a sorption trend with increasing $\mathrm{pH}$ similar to that observed by Shi et al. [20]. The researchers ascribed the higher uptake of $\mathrm{Cr}(\mathrm{VI})$ in acidic conditions to the protonation of amino groups in the chitosan sorbents, which would induce an electrostatic attraction to oxyanion $\mathrm{Cr}(\mathrm{VI})$ species. The same study [25] also reported a slightly lower $\mathrm{Cr}(\mathrm{VI})$ removal efficiency at $\mathrm{pH} 2$ relatively to $\mathrm{pH} 4$, which was attributed to chitosan instability at this $\mathrm{pH}$.

An alternative mechanism for water purification from $\mathrm{Cr}(\mathrm{VI})$ involves reduction to $\mathrm{Cr}(\mathrm{III})$, a process in which $\mathrm{pH}$ also plays a central role $[6,27,28]$. Janos et al. [6] studied the reduction and immobilization of $\mathrm{Cr}(\mathrm{VI})$ with oxyhumolite and iron humate. The authors found that the amount of $\mathrm{Cr}(\mathrm{VI})$ removed from the solution in the presence of oxyhumolite decreased with increasing $\mathrm{pH}$ (Figure 3A).
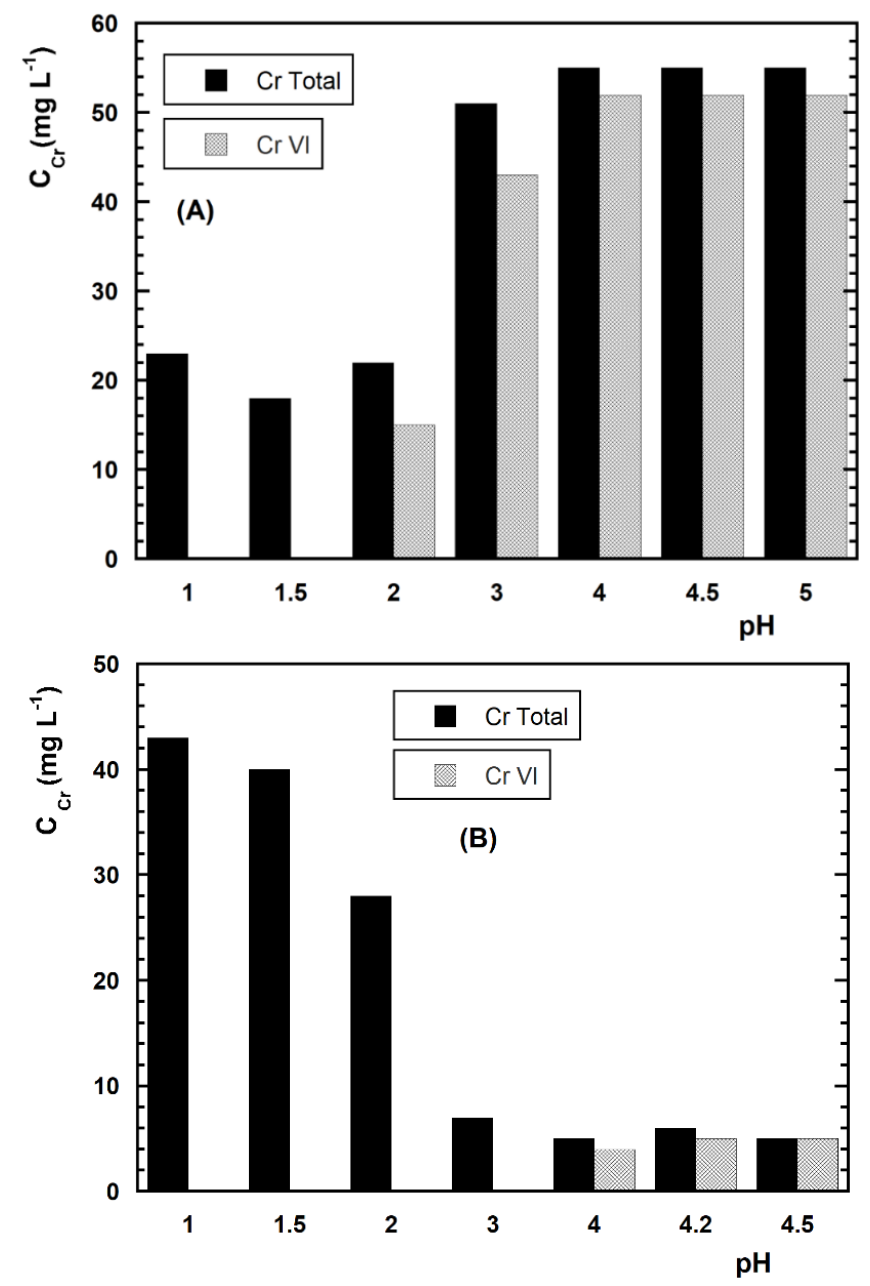

Figure 3. Residual chromium concentration in solution as a function of $\mathrm{pH}$. Sorbent used: (A) oxyhumolite; (B) iron humate. Adapted from Janos et al. [6]. 
Two mechanisms were proposed to account for that, involving direct and indirect reduction of $\mathrm{Cr}(\mathrm{VI})$. In the former mechanism, $\mathrm{Cr}(\mathrm{VI})$ is directly reduced to $\mathrm{Cr}(\mathrm{III})$ in the aqueous phase by contact with electron-donor groups of the sorbent; $\mathrm{Cr}$ (III) thus formed may be sorbed by cation-exchange or remain in solution. The indirect reduction pathway proposed postulates that $\mathrm{Cr}(\mathrm{VI})$ in the oxyanionic form initially binds via electrostatic interaction to the positively charged sorbent surface, then undergoes reduction by adsorbent electron-donor groups and is finally released in solution or remains bound to the sorbent. The study by Janos et al. [6] clearly identified two processes: $\mathrm{Cr}(\mathrm{VI})$ reduction to $\mathrm{Cr}$ (III) favored at lower $\mathrm{pH}$, and $\mathrm{Cr}(\mathrm{III})$ retention by the sorbent favored at higher $\mathrm{pH}$. Interestingly, a somewhat different trend was observed when using iron humate as sorbent (Figure 3B). The authors related this trend to the presence of iron compounds in the sorbent material that might be able to reduce $\mathrm{Cr}(\mathrm{VI})$ over a wide $\mathrm{pH}$ range. The resulting $\mathrm{Cr}^{3+}$ cations might be retained on the sorbent by several mechanisms, such as ion-exchange, covalent binding or surface precipitation and co-precipitation of $\mathrm{Fe}^{3+} / \mathrm{Cr}^{3+}$ hydroxides. It is worth mention that the $\mathrm{pH}$ used by Janos et al. [6] is below 5, hence their results are not strictly comparable with those shown in Figures 2 and 4.

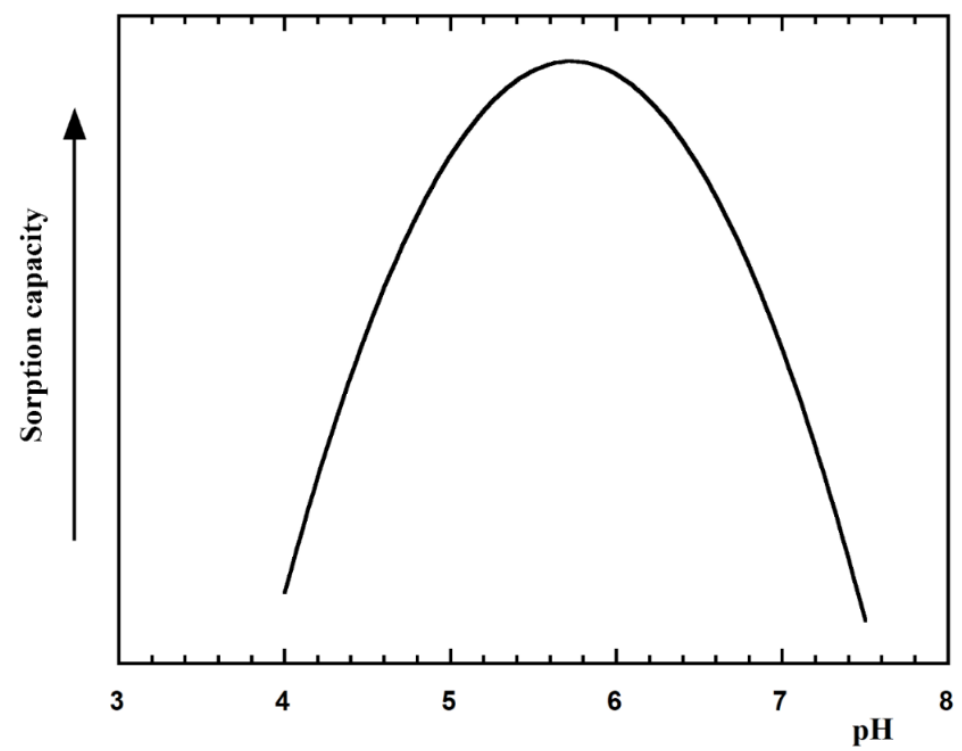

Figure 4. Typical bell-shaped trend of sorption capacity as a function of $\mathrm{pH}$.

Campos [28] examined the performance of powder carbon steel for $\mathrm{Cr}(\mathrm{VI})$ removal from water. This author found a higher $\mathrm{Cr}$ removal efficiency with decreasing $\mathrm{pH}$, probably due to $\mathrm{Cr}(\mathrm{VI})$ reduction to $\mathrm{Cr}(\mathrm{III})$ coupled with oxidation of $\mathrm{Fe}$ to $\mathrm{Fe}^{3+}$. $\mathrm{Fe}^{3+}$ and $\mathrm{Cr}^{3+}$ thus produced could react forming mixed oxide with low solubility and consuming $\mathrm{H}^{+}$. On the other hand, chromate and $\mathrm{Fe}^{2+}$ ions may react and form mixed $\mathrm{Cr}$ and $\mathrm{Fe}$ oxides generating $\mathrm{H}^{+}$release. The following Equations (8) and (9) illustrate some of the reactions discussed above:

$$
\begin{gathered}
\mathrm{Fe}+\mathrm{CrO}_{4}^{2-}+0.5 \mathrm{H}_{2} \mathrm{O}+2 \mathrm{H}^{+} \rightarrow \mathrm{Fe}(\mathrm{OH})_{3}+0.5 \mathrm{Cr}_{2} \mathrm{O}_{3} \\
6 \mathrm{Fe}^{2+}+2 \mathrm{CrO}_{4}^{2-}+13 \mathrm{H}_{2} \mathrm{O} \rightarrow 6 \mathrm{Fe}(\mathrm{OH})_{3}+\mathrm{Cr}_{2} \mathrm{O}_{3}+8 \mathrm{H}^{+}
\end{gathered}
$$

A similar reduction in the sorption capacity with the increasing $\mathrm{pH}$ was observed by Kantar et al. [22], who investigated the sorption and reduction of $\mathrm{Cr}(\mathrm{VI})$ to $\mathrm{Cr}(\mathrm{III})$ using pyrite $\left(\mathrm{FeS}_{2}\right)$. The mechanism proposed by the authors was quite complex, involving a number of simultaneous or sequential steps, including pyrite dissolution, precipitation of oxidation products, protonation/deprotonation of chromium and of oxidized surfaces. A decrease in $\mathrm{Cr}(\mathrm{VI})$ removal efficiency associated with increasing $\mathrm{pH}$ was ascribed, at least in part, to pyrite surface passivation due to the accumulation of oxidation products. Under acidic conditions, pyrite releases $\mathrm{Fe}^{2+}$ which may 
reduce $\mathrm{Cr}(\mathrm{VI})$ to $\mathrm{Cr}(\mathrm{III})$ in the solution phase. Interestingly, the authors also suggested that $\mathrm{Fe}^{2+}$ ions could also be sorbed onto pyrite, thus activating a cyclic redox mechanism that would further favors $\mathrm{Cr}(\mathrm{VI})$ reduction. The overall reaction pathway proposed is:

$$
3 \mathrm{FeS}_{2}+14 \mathrm{HCrO}_{4}^{-}+50 \mathrm{H}^{+} \rightarrow 3 \mathrm{Fe}^{2+}+6 \mathrm{SO}_{4}^{2-}+14 \mathrm{Cr}^{3+}+32 \mathrm{H}_{2} \mathrm{O}
$$

Di Natale et al. [29] used an additive-competitive Langmuir model to describe the effects of both $\mathrm{pH}$ and temperature on the chromium adsorption capacity of a commercial granular activated carbon, accounting for the chromium ion speciation. They highlighted that the optimal $\mathrm{pH}$ conditions were derived from the compensation between higher $\mathrm{Cr}(\mathrm{VI})$ ionization, favored at higher $\mathrm{pH}$, and lower competition with $\mathrm{OH}$ - ions, favored at lower $\mathrm{pH}$.

Ozer et al. [26] investigated the sorption of $\mathrm{Cr}(\mathrm{VI})$ by free and immobilized biomass (Pediastrum boryanum) and observed the typical decreasing sorption trend with increasing $\mathrm{pH}$ (Figure 2). This result was related by the authors to deprotonation of amino groups at the sorbent surface, which would hamper the electrostatic binding of chromium oxyanions.

A distinctive effect of $\mathrm{pH}$ on the sorption of $\mathrm{Cr}(\mathrm{VI})$ was observed by Koujalagi and co-workers [30] using Tulsion A-27(MP) resin (Figure 4). The sorption capacity vs. $\mathrm{pH}$ followed a bell-shaped curve with a maximum in the $\mathrm{pH}$ range 5-6 (Figure 4). The authors ascribed the fall of sorption capacity at high $\mathrm{pH}$ to sorbent surface passivation of the adsorbent surface by precipitation of hydroxides. In contrast, the decrease at low $\mathrm{pH}$ was ascribed to competition of $\mathrm{H}^{+}$with $\mathrm{Cr}(\mathrm{VI})$ for sorption sites.

In the study carried out by Chakrava et al. [31], husk of Lathyrus sativus was used as a sorbent for $\mathrm{Cr}(\mathrm{VI})$. It was found that the presence of functional groups such as ${ }^{-} \mathrm{NH}_{2},{ }^{-} \mathrm{OH}$ and $\mathrm{PO}_{4}{ }^{3-}$ on the biomass surface markedly affected $\mathrm{Cr}(\mathrm{VI})$ uptake. More in detail, the authors suggested that the binding of $\mathrm{Cr}(\mathrm{VI})$ involved hydrogen bonds with amino and hydroxyl groups, or electrostatic interactions with protonated phosphate groups.

A pH effect similar to that displayed in Figure 4 was also found by Wu and co-workers [32] using chitosan-xylan- $\mathrm{TiO}_{2}$ adsorbent. The authors attributed the low sorption of $\mathrm{Cr}(\mathrm{VI})$ in acidic solution $(\mathrm{pH} 4)$ to electrostatic repulsion between the protonated functional groups of the sorbent and positively charged chromium ions. This explanation is not convincing because, as discussed above, at $\mathrm{pH} 4 \mathrm{Cr}(\mathrm{VI})$ is prevalently present as oxyanion. An alternative explanation might be the structural alteration of the sorbent surface in acidic environment and consequent loss of sorption capacity [33-35]. A third mechanism possibly contributing to reduce $\mathrm{Cr}(\mathrm{VI})$ sorption at low $\mathrm{pH}(<2)$ might be the formation of oligomers of chromium species such as $\mathrm{Cr}_{3} \mathrm{O}_{10}{ }^{2-}$ and $\mathrm{Cr}_{4} \mathrm{O}_{13}{ }^{2-}[36,37]$.

Gheju and coworkers studied the sorption of $\mathrm{Cr}(\mathrm{VI})$ onto $\mathrm{MnO}_{2}$ [24]. A pH rise from 5.9 to 8.1 remarkably reduced $\mathrm{Cr}(\mathrm{VI})$ removal. The $\mathrm{pH}$ dependence of the process was ascribed to: (i) an increase in the negative net charge of the sorbent with increasing $\mathrm{pH}$ (being the point of zero charge $\mathrm{pH}_{\mathrm{PZC}}=5.8$ ) and consequent increase of electrostatic repulsion between the sorbent surface and chromium oxyanions; (ii) higher competition between chromium oxyanions and $\mathrm{OH}^{-}$for positive sorption sites with increasing $\mathrm{pH}$.

A bell shape curve such as that shown in Figure 4 was also reported by Hans et al. [38] for the sorption of $\mathrm{Cr}(\mathrm{VI})$ onto $\mathrm{MIEX}{ }^{\circledR}$, a magnetic ion exchange resin. A maximum sorption capacity was observed in the $\mathrm{pH}$ range 4-6. The authors ascribed the reduction in sorption capacity at lower and higher $\mathrm{pH}$ to competition between $\mathrm{Cr}(\mathrm{VI})$ and $\mathrm{H}^{+}$and between $\mathrm{Cr}(\mathrm{VI})$ and $\mathrm{OH}^{-}$, respectively.

$\mathrm{Cr}(\mathrm{VI})$ sorption capacity by siderite $\left(\mathrm{FeCO}_{3}\right)$ in anoxic aqueous solution was lower at $\mathrm{pH} 4$ than at $\mathrm{pH} 5$ and 6 [39]. This phenomenon was ascribed by the authors to reduction of $\mathrm{Cr}(\mathrm{VI})$ to $\mathrm{Cr}(\mathrm{III})$ by $\mathrm{Fe}^{2+}$ on the mineral surface or in solution.

$\mathrm{Cr}(\mathrm{VI})$ sorption capacity of schwertmannite attained a maximum at $\mathrm{pH}$ 6.0 [40]. $\mathrm{Cr}(\mathrm{VI})$ sorption by schwertmannite was mainly attributed to ion exchange between $\mathrm{Cr}(\mathrm{VI})$ and structural $\mathrm{SO}_{4}{ }^{2-}$, a process possible because the $\mathrm{Cr}(\mathrm{VI})$ species and $\mathrm{SO}_{4}{ }^{2-}$ have the same charge and similar sizes.

A novel biochar-supported zero-valent iron stabilized by carbomethyl cellulose was recently developed and used for $\mathrm{Cr}(\mathrm{VI})$ sorption experiments [41]. These experiments revealed that the 
uptake/removal of $\mathrm{Cr}(\mathrm{VI})$ occurred via a complex mechanism involving electrostatic attraction, reduction and surface complexation. The main reactions of the proposed mechanism are reported below:

$$
\begin{gathered}
3 \mathrm{Fe}^{0}+\mathrm{Cr}_{2} \mathrm{O}_{7}^{2-}+14 \mathrm{H}^{+} \rightarrow 3 \mathrm{Fe}^{2+}+2 \mathrm{Cr}^{3+}+7 \mathrm{H}_{2} \mathrm{O} \\
\mathrm{HCrO}_{4}^{-}+7 \mathrm{H}^{+}+3 \mathrm{e}^{-} \leftrightarrow \mathrm{Cr}^{3+}+4 \mathrm{H}_{2} \mathrm{O} \\
3 \mathrm{Fe}^{2+}+\mathrm{HCrO}_{4}^{-}+7 \mathrm{H}^{+} \rightarrow 3 \mathrm{Fe}^{3+}+\mathrm{Cr}^{3+}+4 \mathrm{H}_{2} \mathrm{O} \\
\mathrm{Fe}^{2+}+\mathrm{Cr}_{2} \mathrm{O}_{4}^{2-} \leftrightarrow \mathrm{FeCr}_{2} \mathrm{O}_{4}(\mathrm{~s}) \\
2 \mathrm{Cr}^{3+}+6 \mathrm{OH}^{-} \leftrightarrow 2 \mathrm{Cr}(\mathrm{OH})_{3}(\mathrm{~s}) \leftrightarrow \mathrm{Cr}_{2} \mathrm{O}_{3}(\mathrm{~s})+3 \mathrm{H}_{2} \mathrm{O} \\
\mathrm{xCr} \mathrm{Cr}^{3+}+(1-\mathrm{x}) \mathrm{Fe}^{3+}+3 \mathrm{H}_{2} \mathrm{O} \rightarrow\left(\mathrm{Cr}_{\mathrm{x}} \mathrm{Fe}_{1-\mathrm{x}}\right)(\mathrm{OH})_{3}(\mathrm{~s})+3 \mathrm{H}^{+} \\
\mathrm{xCr^{3+ }}+(1-\mathrm{x}) \mathrm{Fe}^{3+}+3 \mathrm{OH}^{-} \rightarrow\left(\mathrm{Cr}_{\mathrm{x}} \mathrm{Fe}_{1-\mathrm{x}}\right)(\mathrm{OH})_{3}(\mathrm{~s})
\end{gathered}
$$

\section{Equilibrium and Thermodynamic Aspects of Cr(VI) Sorption}

\subsection{Sorption Isotherms}

The sorption equilibrium of $\mathrm{Cr}(\mathrm{VI})$, as for any other sorbate, is generally investigated using the sorption isotherms [42]. These are obtained by plotting the sorbed amount of $\mathrm{Cr}(\mathrm{VI})$ per unit mass of sorbent $\left(q_{e}\right)$ at equilibrium against the initial $\mathrm{Cr}(\mathrm{VI})$ concentration $\left(C_{e}\right)$.

The isotherm models most frequently applied for describing $\mathrm{Cr}(\mathrm{VI})$ sorption are the Langmuir model and the Freundlich model [43].

The Langmuir model [44] (Equation (18)) is a simplistic model applicable under the assumptions that (i) the sorbate encompasses a finite number of energetically equivalent sites arranged in a superficial monolayer, and (ii) the solution behaves ideally (i.e., the solution is diluted enough for solute activity being approximated by concentration), and there are no intermolecular interactions among the free solute and/or sorbate molecules [45,46]:

$$
q_{e}=\frac{q_{m} K_{L} C_{e}}{1+K_{L} C_{e}}
$$

where $q_{m}$ and $K_{L}$ are the maximum sorption capacity and the Langmuir equilibrium constant, respectively.

The Freundlich model [47] (Equation (19)) is a power function empirical model especially useful for the practical purpose of describing sorption equilibrium data not including a sorption saturation level as the Langmuir model demands:

$$
q_{e}=K_{F} C_{e}^{N}
$$

where $K_{F}$ and $N$ are empirical constants. It has been suggested that the value of the $N$ parameter gives information on the heterogeneity of sorbent sites: values of $N$ significantly lower than 1 (concave downward isotherms) would reflect high heterogeneity, whereas values of $N \cong 1$ (linear isotherms) would be indicative of a homogeneous energetic distribution of sorption sites. It is important to note that $N$ is a dimensionless parameter. This notwithstanding, $N$ is sometimes erroneously reported with units of $\mathrm{L} \mathrm{mg}^{-1}[48,49]$.

With few exceptions [18,50-52], if compared to, the Langmuir model fits better than the Freundlich model the experimental data for $\mathrm{Cr}(\mathrm{VI})$ sorption. Liu et al. [53] obtained a higher correlation coefficient using the Langmuir model for modelling the sorption isotherms of $\mathrm{Cr}(\mathrm{VI})$ sorption by poly $\left(\mathrm{N}^{1}, \mathrm{~N}^{1}, \mathrm{~N}^{3}, \mathrm{~N}^{3}\right.$-tetraallylpropane-1,3-diaminium chloride) (PTAPDAC). A better performance of the Langmuir model was confirmed by Anandaraj et al. [54] using native and chemically modified green macroalgae Codium tomentosum biomass as a sorbent. Similar results were obtained by Mikhaylov et al. [8] using $\mathrm{Al} / \mathrm{Fe}$ oxyhydroxide composite powders, Sutkowy and Klosowsky [55] using the 
green alga Pseudopediastrum boryanum and many other authors using minerals [40,56], synthetized materials $[1,7,10,20,57,58]$ or biosorbents $[26,27,48,59]$.

In some cases $[6,25,60]$, a semi-empirical hybrid Langmuir-Freundlich model, also known as Sips model [61], has been used for modelling isotherm equilibrium data:

$$
q_{e}=\frac{q_{m} K_{L F} C_{e}^{N}}{1+K_{L F} C_{e}^{N}}
$$

where $K_{L F}$ is a constant.

The Sips model generally gives better fitting results than either the Langmuir or the Freundlich model. This is not surprising, because the Sips model is a more general (and therefore adaptable) equation that, for $N=1$ or for high $\mathrm{Cr}(\mathrm{VI})$ initial concentration, reduces to the Langmuir model whereas for sufficient low $\mathrm{Cr}(\mathrm{VI})$ concentration (i.e., $1>>K_{L F} C_{e}{ }^{N}$ ) reduces to the Freundlich model (with $K_{F}=q_{m} K_{L F}$ ).

In rare cases, the equilibrium sorption data exhibited unusual trends not amenable to modelling by any of the isotherm equations described above. For example, Gheju and coworkers [24] reported a bell-shaped isotherm curve for the sorption of $\mathrm{Cr}(\mathrm{VI})$ onto $\mathrm{MnO}_{2}$. Normally, sorption capacity increases with increasing sorbate initial concentration and eventually reaches a plateau that corresponds to the saturation level of the sorbent. In contrast, the sorption capacity of the sorbent was higher at low chromium concentration and declined at higher concentration. The authors attributed this unusual behavior to $\mathrm{HCrO}_{4}{ }^{-}$dimerization to $\mathrm{Cr}_{2} \mathrm{O}_{7}{ }^{2-}$. Because of its larger volume, $\mathrm{Cr}_{2} \mathrm{O}_{7}{ }^{2-}$ has more difficult access to sorption sites, thus reducing the sorption capacity of $\mathrm{MnO}_{2}$.

\subsection{Maximum Sorption Capacity}

A most important parameter for evaluating sorbent efficiency is the maximum (saturation) sorption capacity, $q_{m}$, as determined from the plateau level of the experimental isotherm. A list of values of $q_{m}$ for different sorbents is given in Table 1. It is important to note that the $q_{m}$ values reported here may not be strictly comparable because, as discussed above, the $\mathrm{Cr}(\mathrm{VI})$ sorption capacity may vary with operative conditions such as $\mathrm{pH}$ and temperature. The highest maximum sorption capacity for $\mathrm{Cr}(\mathrm{VI}), 12.0 \mathrm{mmol} \mathrm{g}^{-1}$, was reported by Setshedi et al. [62] for a polypyrrole graphene oxide nanocomposite. High values of $q_{m}$ were also found for nanosilica immobilized-fungi ( $q_{m}=10.1 \mathrm{mmol}$ $\left.\mathrm{g}^{-1}\right)$ [36], grafted aerobic granular sludge $\left(q_{m}=7.7 \mathrm{mmol} \mathrm{g}^{-1}\right)$ [60], and chitosan/poly(vinyl amine) cryogel $\left(q_{m}=6.1 \mathrm{mmol} \mathrm{g}^{-1}\right)[63]$. 
Table 1. Thermodynamic data for $\mathrm{Cr}(\mathrm{VI})$ sorption.

\begin{tabular}{|c|c|c|c|c|c|c|c|c|c|c|c|}
\hline Sorbent Type & $q_{m}\left(\mathrm{mmol} \mathrm{g}^{-1}\right)$ & $K_{L}\left(\mathrm{~L} \mathrm{mmol}^{-1}\right)$ & $q_{m} K_{L}\left(\mathrm{~L} \mathrm{~g}^{-1}\right)$ & $K_{F}\left(\mathrm{mmol}^{1-\mathrm{N}} \mathrm{L}^{\mathrm{N}} \mathrm{g}^{-1}\right)$ & $N$ & $T\left({ }^{\circ} \mathrm{C}\right)$ & $\Delta H^{\circ}\left(\mathrm{kJ} \mathrm{mol}^{-1}\right)$ & $\Delta S^{\circ}\left(\mathrm{J} \mathrm{K}^{-1} \mathrm{~mol}^{-1}\right)^{\circ}$ & $\Delta G^{\circ}\left(\mathrm{kJ} \mathrm{mol}^{-1}\right)$ & $\mathrm{pH}$ & Ref. \\
\hline Magnetic ion exchange resin & 1.781 & 181 & 322.4 & 1 & I & 25 & I & 1 & 1 & 4 & [38] \\
\hline Zero-valent iron-carboxymethyl cellulose & 2.163 & 16.59 & 35.88 & 1.856 & 0.230 & 25 & 1 & 1 & 1 & 5.6 & [41] \\
\hline Siderite & I & 1 & 1 & 1.408 & 0.130 & 20 & I & I & 1 & 5 & [39] \\
\hline Zirconium oxide-alginate beads & 0.200 & 1.633 & 0.327 & 0.109 & 0.466 & 25 & 21.224 & 163 & -27.430 & 5 & [58] \\
\hline $\mathrm{Mg}-\mathrm{Al}$ hydrotalcite & 1.383 & 22.26 & 30.79 & 1.723 & 0.40 & Room & I & I & 1 & 6 & [35] \\
\hline Anion exchanger chitosan/poly(vinyl amine) & 6.114 & 0.974 & 5.955 & 2.673 & 0.345 & 25 & 61.11 & 219 & -4.18 & 5.5 & [63] \\
\hline Cross linked-chitosan-polyaniline & 3.446 & 5.928 & 20.43 & 2.943 & 0.227 & 30 & 13.46 & 10 & -9.18 & 4.2 & [64] \\
\hline Mg-Zn-Al hydrotalcite derived oxides & $0.961 *$ & I & I & I & I & 30 & I & I & I & 6 & [65] \\
\hline Fe (II)-modified natural zeolite & $5.769 \times 10^{-3 *}$ & 1 & 1 & 1 & 1 & Room & 1 & 1 & 1 & 5.5 & [66] \\
\hline Anion-exchange resins & 3.005 & 81.19 & 244.0 & 3.084 & 0.151 & 27 & 0.016 & 39.88 & -4.498 & 5 & [20] \\
\hline $\mathrm{MnO}_{2}$ & $0.016^{*}$ & 1 & 1 & 1 & 1 & 20 & -22.52 & -50.40 & -8.08 & 6.9 & [24] \\
\hline Schwert- mannite & 1.890 & 3.04 & 5.746 & 0.97 & 0.313 & 25 & I & I & I & 6 & [40] \\
\hline Iron/carbon $\mathrm{Fe} / \mathrm{C}$ composites & 0.981 & 5.782 & 5.672 & 0.998 & 0.483 & Room & 1 & 1 & 1 & 5 & [27] \\
\hline Cereal by-product carbon & $2.300^{*}$ & I & I & I & I & 20 & 0.7142 & -94.8 & 28.479 & 6 & [4] \\
\hline Calcinated Al/Fe oxide-oxyhydroxide & 0.074 & 123.4 & 9.132 & 0.0837 & 0.104 & Room & 1 & I & 1 & 6.7 & [67] \\
\hline Polyethylenimine grafted sludge & 7.721 & 4.16 & 32.12 & 2.241 & 0.48 & 25 & 1 & I & 1 & 5.5 & [60] \\
\hline Nannochloris oculata & 0.725 & 0.530 & 0.384 & 0.215 & 0.67 & I & 1 & 1 & 1 & 2 & [50] \\
\hline Amine-functionalized corn stalk & 4.370 & 10.92 & 47.72 & 3.474 & 0.128 & 45 & 96.79 & 30 & -7.16 & 3 & [68] \\
\hline Dolomite & 0.192 & 14.14 & 2.715 & 0.203 & 0.304 & 20 & -13.21 & -22.47 & -6.617 & 2 & [51] \\
\hline Acinetobacter junii VITSUKMW2 & 0.436 & 115.5 & 50.36 & 0.0506 & 0.389 & 27 & -3.764 & 0.018 & -1.989 & 2 & [48] \\
\hline Polypyrrole graphene oxide & 12.030 & 104 & 1251 & 11.68 & 0.029 & 25 & 78.417 & 282.67 & -7.287 & 2 & [62] \\
\hline $\mathrm{Al} / \mathrm{Fe}$ oxide-oxyhydroxide & 0.070 & 54.6 & 3.82 & 0.103 & 0.26 & I & 1 & I & 1 & 5.4 & [8] \\
\hline Sargassum bevanom & 0.763 & 1158.8 & 884.2 & 0.484 & 0.342 & 20 & 28.656 & 115 & -5.256 & 3 & [19] \\
\hline Iron oxide-activated carbon & 0.155 & 8.84 & 1.370 & 0.119 & 0.37 & 25 & 49.906 & 168.3 & -0.293 .3 & 2 & [49] \\
\hline Ash gourd (Benincasa hispida) waste & $0.360 *$ & 1 & 1 & 0.472 & 0.25 & 28 & 1 & 1 & 1 & 1 & [69] \\
\hline Chitosan-xylan- $\mathrm{TiO}_{2}$ & 1.867 & 1.217 & 2.272 & 0.904 & 0.50 & 45 & 4.44 & 35.98 & -7.00 & 7 & [32] \\
\hline Teff straw & 1.656 & 86.30 & 142.9 & 2.166 & 0.277 & 45 & 34.25 & 150.07 & -13.468 & 2 & [70] \\
\hline Sawdust & 0.870 & 47.32 & 41.17 & 12.24 & 0.813 & 40 & 34.67 & 124.1 & -4.2140 & 3 & [52] \\
\hline Codium tomentosum & 0.105 & 11.44 & 1.201 & 0.228 & 0.622 & 20 & I & l & I & 2 & [54] \\
\hline Vinylpyridine divinylbenzene & 4.130 & 2.777 & 11.47 & 1 & 1 & 25 & 1 & I & 1 & 2 & [71] \\
\hline$\beta$-Cyclodextrin-polyurethane & 0.045 & 52 & 2.34 & 9.739 & 0.25 & 25 & 1 & I & 1 & 3 & [72] \\
\hline Husk of Lathyrus sativus & 0.940 & 4.493 & 4.223 & 0.214 & 0.073 & 30 & 1 & 1 & 1 & 2 & [31] \\
\hline
\end{tabular}


Table 1. Cont.

\begin{tabular}{|c|c|c|c|c|c|c|c|c|c|c|c|}
\hline Sorbent Type & $q_{m}\left(\mathrm{mmol} \mathrm{g}^{-1}\right)$ & $K_{L}\left(\mathrm{~L} \mathrm{mmol}^{-1}\right)$ & $q_{m} K_{L}\left(\mathrm{~L} \mathrm{~g}^{-1}\right)$ & $K_{F}\left(\mathrm{mmol}^{1-\mathrm{N}} \mathrm{L}^{\mathrm{N}} \mathrm{g}^{-1}\right)$ & $N$ & $T\left({ }^{\circ} \mathrm{C}\right)$ & $\Delta H^{\circ}\left(\mathrm{kJ} \mathrm{mol}^{-1}\right)$ & $\Delta S^{\circ}\left(\mathrm{J} \mathrm{K}^{-1} \mathrm{~mol}^{-1}\right)^{\circ}$ & $\Delta G^{\circ}\left(\mathrm{kJ} \mathrm{mol}^{-1}\right)$ & $\mathrm{pH}$ & Ref. \\
\hline Organoclay & 0.045 & 38.06 & 1.713 & 0.698 & 0.885 & 25 & 1 & 1 & I & 2 & [56] \\
\hline Resin Tulsion A-27 & 1.620 & 0.370 & 0.599 & 2.64 & 0.144 & 50 & -9.9 & 10.2 & -13.2 & 5.5 & [30] \\
\hline Nanosilica-immobilized fungi & 10.120 & 0.0267 & 0.270 & 0.804 & 0.442 & 25 & 1 & 1 & 1 & 2 & [36] \\
\hline Solid biodiesel waste residue & 2.530 & 0.936 & 2.368 & 1.119 & 0.431 & 30 & -9.34 & -23.27 & -2.040 & 2 & [73] \\
\hline Fe-modified peanut husk & 0.637 & 0.52 & 0.331 & 0.199 & 0.557 & 30 & -9087 & -32.488 & 753.94 & 2 & [74] \\
\hline Pediastrum boryanum & 0.585 & 11.08 & 6.482 & 0.456 & 0.254 & 25 & 44.5 & 251 & -17.4 & 2 & [26] \\
\hline Trewia nudiflora & 5.656 & 11.08 & 62.67 & 4.917 & 0.273 & 30 & 20.11 & 110 & -13.22 & 2 & [75] \\
\hline Metal organic resin-2 & 3.725 & 3.64 & 13.56 & I & I & 1 & 1 & 1 & 1 & 3 & [76] \\
\hline Polytetraallylpropane diaminium & 5.253 & 21.48 & 112.8 & 0.357 & 0.297 & 20 & -7.042 & 52.401 & -22.395 & 6 & [53] \\
\hline Polyelectrolytic hydrogels & 0.790 & 2.132 & 1.684 & 0.612 & 0.322 & 30 & 1 & I & 1 & 6 & [1] \\
\hline Amine-magnetite nanoparticles & 4.079 & 16.33 & 66.61 & 0.149 & 0.488 & 25 & 137.1 & 26.91 & -3.28 & 3 & [2] \\
\hline L-Cysteine magnetite & 0.663 & 215.3 & 142.7 & 2.512 & 0.293 & 45 & 73.31 & 280 & -14.7 & 2 & [10] \\
\hline Ustilago maydis & 2.530 & 0.300 & 0.759 & $2.4 \times 10^{-2}$ & 0.52 & 20 & -9745 & -38.685 & 856.54 & 2 & [77] \\
\hline Amine silica magnetite & 3.561 & 1 & 1 & I & 1 & Room & I & 1 & I & 2 & [57] \\
\hline Nano- $\gamma-\mathrm{Al}_{2} \mathrm{O}_{3}$ & 0.267 & 101.4 & 27.07 & 0.318 & 0.161 & 25 & 1 & 1 & 1 & 3 & [78] \\
\hline Pteris vittata $\mathrm{L}$. & 3.206 & 1.56 & 5.001 & 1.179 & 0.27 & 30 & 21.0 & 200 & -26.5 & 2 & [59] \\
\hline Chitosan magnetite & 3.846 & 1.3 & 5.000 & 1.743 & 0.854 & 30 & 25.72 & 182 & -29.4 & 3 & [7] \\
\hline Aspergillus niger & 0.097 & 1142.3 & 110.8 & $2.14 \times 10^{-3}$ & 0.666 & 28 & 1 & 1 & 1 & 2.5 & [37] \\
\hline $\mathrm{Mg}_{6} \mathrm{AlFe}$-double hydroxide & 3.385 & 0.0952 & 0.322 & 0.489 & 0.495 & 25 & 1 & 1 & 1 & 5 & [79] \\
\hline Alum-water treatment sludge & 0.220 & 1.12 & 0.246 & 0.011 & 0.44 & 25 & 1 & I & 1 & 3 & [18] \\
\hline Palm kernel shell & 0.955 & 113.7 & 108.6 & 0.0958 & 0.62 & Room & 1 & 1 & 1 & 6 & [80] \\
\hline Bacterial cellulose/ chitosan & $2.925^{*}$ & 1 & 1 & 1 & 1 & 25 & 1 & 1 & 1 & 6 & [81] \\
\hline Kaolinite nanotubes & 4.579 & 0.143 & 0.655 & 0.0536 & 0.89 & 30 & 1 & I & 1 & 2 & [82] \\
\hline Bacterial cellulose/attapulgite & 1.750 & 2.205 & 3.859 & 0.526 & 0.45 & 25 & 1 & l & 1 & 6 & [83] \\
\hline Char derived from South African coal & 0.006 & 7.323 & 0.044 & 0.0096 & 0.665 & & 1 & I & 1 & 2 & [43] \\
\hline Granular activated carbon & 0.138 & 15.334 & 2.116 & 0.2433 & 0.611 & & 1 & 1 & 1 & 7.5 & [43] \\
\hline
\end{tabular}

* Experimental data. 


\subsection{Sorbent Affinity toward Cr(VI)}

The sorbent affinity toward $\mathrm{Cr}(\mathrm{VI})$ can be evaluated from the Langmuir equilibrium constant $\left(K_{L}\right)$ : the higher $K_{L}$ the higher the sorbent affinity for $\mathrm{Cr}(\mathrm{VI})$. Among tested sorbents (Table 1), Sargassum bevanom $\left(K_{L}=1160 \mathrm{~L} \mathrm{mmol}^{-1}\right)$ [19] and Aspergillus niger $\left(K_{L}=1140 \mathrm{~L} \mathrm{mmol}^{-1}\right)$ [37] exhibit the highest affinity for $\mathrm{Cr}(\mathrm{VI})$, followed by L-cysteine functionalized magnetite $\left(K_{L}=215 \mathrm{~L} \mathrm{mmol}^{-1}\right)$ [10], magnetic ion exchange resin $\left(K_{L}=181 \mathrm{~L} \mathrm{mmol}^{-1}\right)$ [38] and calcinated $\mathrm{Al} / \mathrm{Fe}$ oxide-oxyhydroxide composite $\left(K_{L}=123 \mathrm{~L} \mathrm{mmol}^{-1}\right)$ [67]. For practical purposes, it is also relevant to evaluate sorbent affinity at low $\mathrm{Cr}(\mathrm{VI})$ initial concentration. This parameter can be estimated from the initial slope of the Langmuir isotherm, which is the product of the maximum sorption capacity, $q_{m}$, and $K_{L}$. The highest values for $\mathrm{Cr}(\mathrm{VI})$ affinity at low $\mathrm{Cr}(\mathrm{VI})$ concentration have been reported for polypyrrole graphene oxide nanocomposite [62] and Sargassum bevanom [19] (see Table 1).

\subsection{Sorption Thermodynamics}

The change of sorption isotherms (i.e., of the equilibrium conditions) with temperature provides information on the temperature-dependence of the sorption equilibrium and related thermodynamic parameters, namely the standard change in Gibbs energy $\left(\Delta G^{\circ}\right)$, enthalpy $\left(\Delta H^{\circ}\right)$ and entropy $\left(\Delta S^{\circ}\right)$.

The temperature-dependence of the sorption equilibrium constant $(K)$ is generally derived from the Gibbs-Helmholtz equation [84]:

$$
\frac{\partial\left(\Delta G^{\circ} / T\right)}{\partial T}=-\frac{\Delta H^{\circ}}{T^{2}}
$$

By using the well-known thermodynamic relationships:

$$
\begin{gathered}
\Delta G^{\circ}=-R T \ln (K) \\
\Delta G^{\circ}=\Delta H^{\circ}-T \Delta S^{\circ}
\end{gathered}
$$

and assuming that neither $\Delta H^{\circ}$ or $\Delta S^{\circ}$ varies appreciably with temperature, Equation (21) can be integrated to give:

$$
\ln (K)=-\frac{\Delta H^{\circ}}{R} \frac{1}{T}+\frac{\Delta S^{\circ}}{R}
$$

A plot of $\ln K$ vs. 1/T (van't Hoff plot) will produce a straight line whose slope and intercept with $\mathrm{y}$-axis permit the determination of $\Delta H^{\circ}$ and $\Delta S^{\circ}$, respectively.

The value of $K$ in Equation (24) depends on the model chosen for describing the sorption isotherm. The Langmuir equilibrium constant $K_{L}$ is often used for this purpose in $\mathrm{Cr}(\mathrm{VI})$ sorption studies [35,51,75]; the sorption distribution coefficient $K_{D}=q_{e} / C_{e}$ (determined by extrapolating to zero the plot $\ln \left(q_{e} / C_{e}\right)$ against $\left.C_{e}\right)$ is also utilized, though less frequently $[32,64,70]$.

Applying Equation (24), Kumar et al. [58] obtained positive values of $\Delta H^{\circ}$, indicating that $\mathrm{Cr}(\mathrm{VI})$ sorption on zirconium oxide-immobilized alginate beads is an endothermic process. The same was reported by Dragan et al. [63] using anion exchanger microspheres embedded into chitosan/poly(vinyl amine), by Song et al. [68] using amine-functionalized magnetic corn stalk composites, and by many other authors (Table 1). Negative values of $\Delta H^{\circ}$ are encountered less frequently in the literature, for example Gheju et al. [24] using $\mathrm{MnO}_{2}$ and Albadarin et al. [51] using dolomite.

Crucially thermodynamic analyses of $\mathrm{Cr}(\mathrm{VI})$ sorption reported in the literature is often wrong $[2,7,19,20,24,26,30,35,52,53,58,62,68,73,74,77]$. The value of $K$ (Equation (24)) has been erroneously determined on many occasions $[2,7,20,24,30,52,53,58,62,68,73,77]$ using the following expression:

$$
K=\frac{q_{e}}{C_{e}}
$$

As easily inferred from any experimental isotherm curve (with the exception of linear isotherms), the $q_{e} / C_{e}$ ratio is not constant (i.e., it varies with sorbent coverage [85]), thus Equation (25) does not 
represent an equilibrium constant and cannot be used in the van't Hoff equation (Equation (24)). As already observed, a correct determination of $K$ from the $q_{e} / C_{e}$ ratio could be obtained by extrapolating its value at zero sorbent coverage [86-88].

For the same reasons, we consider incorrect the determination of $K$ as:

$$
K=\frac{F_{e}}{1-F_{e}}
$$

where $F_{e}$ is the fraction of $\mathrm{Cr}(\mathrm{VI})$ sorbed at equilibrium $[19,74]$.

Another mistake frequently observed in the literature concerns the meaning ascribed to the sign of $\Delta G^{\circ}$. Several authors $[2,7,19,20,24,26,32,35,52,53,58,62,64,68,73]$ found a $\Delta G^{\circ}<0$ and interpreted this as an indication of spontaneous $\mathrm{Cr}(\mathrm{VI})$ sorption. Others obtained a $\Delta G^{\circ}>0$ and concluded that the instance of $\mathrm{Cr}(\mathrm{VI})$ sorption they examined was a non-spontaneous process $[4,74,77]$. These claims have been so long held that one tends to forget that the calculated change in Gibbs energy refers to standard conditions. A negative or positive $\Delta G^{\circ}$ only indicates the spontaneity or non-spontaneity, respectively, of a hypothetical sorption process in which the reagents (sorbent and solute) and the product (adsorbent-solute adduct) are both in standard conditions [88]. The sign of $\Delta G^{\circ}$ may even depend on the selected standard state $[88,89]$. It is worth remarking that the choice of the standard state not only influences the sign of $\Delta G^{\circ}$ (hence the value of $K$ [90]), but also the sign and magnitude of $\Delta S^{\circ}\left(\Delta H^{\circ}\right.$ is independent on the standard state because the ratio between $K$ values at two different standard states is constant (see Equation (24)). From the above considerations, it follows that, for a correct comparison of thermodynamic parameters for sorption on different sorbents, these should be relative to similar standard conditions.

\section{Kinetic Modelling}

The study of sorption kinetics is of practical significance because it provides information on the time required for effective removal of a solute from the aqueous phase.

Among the models proposed for describing the kinetics of $\mathrm{Cr}(\mathrm{VI})$ sorption, the most popular ones are the pseudo-first order (PFO) and the pseudo-second order (PSO) model; other frequently used models are the Weber-Morris and the Elovich model.

The PFO model [91] assumes that the observed rate of sorption $(d q / d t)$ is proportional to the distance from equilibrium expressed as the difference between the amount of $\mathrm{Cr}(\mathrm{VI})$ sorbed at equilibrium $\left(q_{e}\right)$ and at any time $(q)$ :

$$
\frac{d q}{d t}=k_{P F O}\left(q_{e}-q\right)
$$

where $k_{P F O}$ is the PFO kinetic rate constant. By integrating Equation (27) for the boundary conditions $t$ $=0$ to $t=t$ and $q=0$ to $q=q$, we obtain:

$$
q=q_{e}\left(1-e^{-k_{P F O} t}\right)
$$

The PSO model [92] differs from the PFO model because the sorption rate is assumed to be proportional to the square of the distance from equilibrium:

$$
\frac{d q}{d t}=k_{P S O}\left(q_{e}-q\right)^{2}
$$

Here $k_{P S O}$ is the PSO kinetic rate constant. Equation (29) can be integrated, for the same boundary conditions as for Equation (27), leading to:

$$
q=\frac{q_{e}{ }^{2} k_{P S O} t}{1+q_{e} k_{P S O} t}
$$


It is widely maintained that the application of the PSO model to $\mathrm{Cr}(\mathrm{VI})$ sorption kinetic data gives better fitting results than the PFO model. Examples include studies carried out using as sorbent bacterial cellulose/attapulgite magnetic composites [83], palm oil kernel shell [80], cross linked-chitosan-grafted-polyaniline composite [64], teff straw [70] and material derived from harmful algal bloom biomass [27]. In contrast, Dragan et al. [63] found that the PFO model was best suited to describe the kinetic data of $\mathrm{Cr}(\mathrm{VI})$ sorption onto chitosan/poly(vinyl amine cryogel. Better applicability of the PFO model appears to be associated with weak $\mathrm{Cr}(\mathrm{VI})$-sorbent interaction (physiosorption) [63], whereas better applicability of the PSO model is indicative of strong interaction (chemisorption) [41]. Noticeably, better performance of the PSO model may also be an artifact from improper analysis of the data. In most cases this results from the application of Equation (30) in the following linearized form [17,93]:

$$
\frac{t}{q}=\frac{1}{k_{P S O} q_{e}^{2}}+\frac{t}{q_{e}}
$$

According to Equation (31), if the data obey the pseudo-second order model, a plot of $t / q$ vs. $t$ should produce a straight line. The main drawback of this method is that for data points at (or very close to) equilibrium, the plot of $t / q$ vs. $t$ becomes linear independently of sorption kinetics [93]. The goodness of the results obtained by the plot of $t / q$ vs. $t$ may be verified by using a linearized form of the PSO model [17]:

$$
\frac{q}{t}=k_{P S O} q_{e}^{2}-k_{P S O} q_{e} q
$$

If the PSO model is appropriate for the data, the plot of $q / t$ against $q$ will be linear. As an example, the comparison between $t / q$ vs. $t$ and $q / t$ vs. $q$ for the sorption of $\mathrm{Cr}(\mathrm{VI})$ onto $\mathrm{MnO}_{2}$ [24] is reported in Figure 5. The authors claimed that the sorption kinetics was adequately described by the PSO model because the linear curve-fitting of $t / q$ vs. $t$ data gave excellent results $\left(R^{2}=0.999\right.$, see Figure 5$)$. However, as can be seen from Figure 5, this conclusion is incorrect because the same data, rearranged in the form $q / t$ vs. $q$, significantly deviate from linearity.

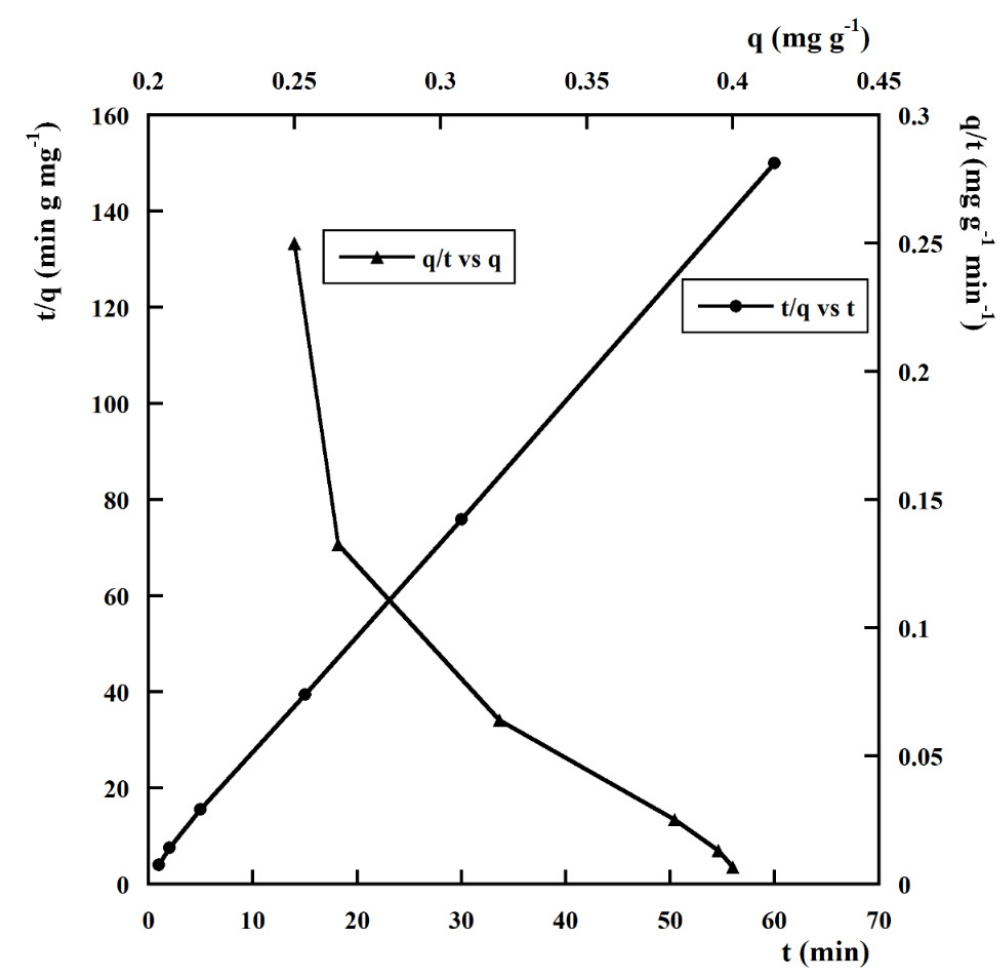

Figure 5. Comparison between the plots of $q$ vs. $t$ and $q / t$ vs. $q$ for the sorption of $\mathrm{Cr}(\mathrm{VI})$ onto $\mathrm{MnO}_{2}$; initial $\mathrm{Cr}(\mathrm{VI})$ aqueous concentration $=0.02 \mathrm{mM}$, sorbent dosage $=2 \mathrm{~g} \mathrm{~L}^{-1}$. Adapted from Gheju et al. [24]. 
As a general rule, the non-linear curve fitting is recommended over the linear curve fitting to prevent possible misinterpretation of the data. It is also worth observing that, because $\mathrm{Cr}(\mathrm{VI})$ sorption rate varies with operative conditions such as the initial solute concentration and the sorbent dosage, it is usually not possible to compare the values of $k_{P F O}$ or $k_{P S O}$ from different reports. To partially overcome this problem, one could, for example, compare the values of initial sorption rate $\left(v_{0}\right)$ as predicted by the PFO and the PSO model, using Equations (33) and (34), respectively:

$$
\begin{gathered}
v_{0(P F O)}=k_{P F O} q_{e} \\
v_{0(P S O)}=k_{P S O} q_{e}{ }^{2}
\end{gathered}
$$

Values of $v_{0(P F O)}$ and $v_{0(P S O)}$ from recent works are reported in Table 2. With very few exceptions [32,53], most of the studies report higher values of $v_{0(P S O)}$ compared to $v_{0(P F O)}$. 
Table 2. Kinetic data for $\mathrm{Cr}(\mathrm{VI})$ sorption.

\begin{tabular}{|c|c|c|c|c|c|c|c|c|c|c|c|}
\hline & & & & PFO M & & & PSO Model & & & & \\
\hline Sorbent Type & $C_{0}\left(\mathrm{mmol} \mathrm{L}^{-1}\right)$ & Sorbent Dosage $\left(\mathrm{g} \mathrm{L}^{-1}\right)$ & $q_{e}\left(\mathrm{mmol} \mathrm{g}^{-1}\right)$ & $k_{P F O}\left(\mathrm{~h}^{-1}\right)$ & $v_{0(P F O)}\left(\mathrm{mmol} \mathrm{g}^{-1} \mathrm{~h}^{-1}\right)$ & $q_{e}\left(\mathrm{mmol} \mathrm{g}^{-1}\right)$ & $k_{P S O}\left(\mathrm{~g} \mathrm{mmol}^{-1} \mathrm{~h}^{-1}\right)$ & $v_{0(P S O)}\left(\mathrm{mmol} \mathrm{g}^{-1} \mathrm{~h}^{-1}\right)$ & $\mathrm{T}\left({ }^{\circ} \mathrm{C}\right)$ & $\mathrm{pH}$ & Ref. \\
\hline Magnetic ion exchange resin & 1.00 & 1 & 0.77 & 9.6 & 7.392 & 0.81 & 29.4 & 19.29 & 25 & 4 & [38] \\
\hline Zero-valent iron-carboxymethyl cellulose & 1.92 & 0.75 & 1.648 & 0.78 & 1.285 & 1.629 & 0.822 & 2.181 & 25 & 5.6 & [41] \\
\hline Zirconium oxide-alginate beads & 0.365 & 2.5 & 0.0409 & 0.0624 & $2.552 \times 10^{-3}$ & 0.0388 & 3.156 & $4.751 \times 10^{-3}$ & 25 & 5 & [58] \\
\hline Mg-Al hydrotalcite & 3.85 & 2 & 1.471 & 9.9 & 14.56 & 1.468 & 9.36 & 20.17 & Room & 6 & [35] \\
\hline Anion exchanger chitosan/poly(vinyl amine) & 1.92 & 1.25 & 1.482 & 1.112 & 1.648 & 1.595 & 1.091 & 2.775 & 25 & 5.5 & [63] \\
\hline Cross linked-chitosan-polyaniline & 7.69 & 2 & 1 & 10.44 & & 3.293 & 12.43 & 134.8 & 30 & 4.2 & [64] \\
\hline Mg-Zn-Al hydrotalcite derived oxides & 0.192 & 5 & 0.886 & 2.1 & 1.861 & 1.147 & 1.751 & 2.304 & 30 & 6 & [65] \\
\hline Fe (II)-modified natural zeolite & 2.88 & 200 & 1 & 1 & 1 & 0.0157 & 700 & 0.0173 & Room & 5.5 & [66] \\
\hline Anion-exchange resins & 1.92 & 1.67 & 0.0577 & 3.624 & 0.209 & 1 & 1 & 1 & 27 & 5 & [20] \\
\hline $\mathrm{MnO}_{2}$ & 0.04 & 2 & $8.07 \times 10^{-3}$ & 3.72 & 0.0300 & 0.0102 & 5678.4 & 0.591 & 20 & 6.9 & [24] \\
\hline Iron/carbon Fe/C composites & 1.92 & 1 & 0.628 & 0.0074 & $4.647 \times 10^{-3}$ & 0.836 & 0.0392 & 0.0328 & Room & 5 & [27] \\
\hline Cereal by-product carbon & 2.54 & 2 & $8.358 \times 10^{-3}$ & 0.120 & $1.00 \times 10^{-3}$ & 0.149 & $13.55 \times 10^{5}$ & $30.08 \times 10^{4}$ & 20 & 6 & [4] \\
\hline Amine-functionalized corn stalk & 3.85 & 1 & 2142.4 & 0.462 & 989.8 & 3.698 & 134.16 & 1834.7 & 45 & 3 & [68] \\
\hline Dolomite & 0.961 & 1 & 0.194 & 0.0452 & $8.769 \times 10^{-3}$ & 0.249 & 0.179 & 0.011 & 20 & 2 & [51] \\
\hline Acinetobacter junii VITSUKMW2 & 1.92 & 2 & 0.202 & 1.08 & 0.218 & 0.492 & 12.48 & 3.021 & 27 & 2 & [48] \\
\hline Polypyrrole graphene oxide & 1.92 & 0.5 & 5.215 & 2.136 & 11.14 & 3.846 & 6.24 & 92.30 & 25 & 2 & [62] \\
\hline Sargassum bevanom & 1.92 & 7 & 1 & 1 & 1 & 0.274 & 16.91 & 1.269 & 20 & 3 & [19] \\
\hline Iron oxide-activated carbon & 0.961 & 5 & $5.96 \times 10^{-3}$ & 6.36 & 0.0380 & 0.0460 & 6895.2 & 14.59 & 25 & 2 & [49] \\
\hline Chitosan-xylan- $\mathrm{TiO}_{2}$ & 1.92 & 5 & 1.760 & 0.593 & 1.044 & 1.273 & 0.551 & 0.893 & 45 & 7 & [32] \\
\hline Teff straw & 1.92 & 10 & 0.137 & 1.68 & 0.230 & 0.175 & 15.6 & 0.478 & 45 & 2 & [70] \\
\hline Codium tomentosum & & 10 & 1 & 1 & 1 & 1 & 1 & 1 & 20 & 2 & [54] \\
\hline$\beta$-Cyclodextrin-polyurethane & 0.0192 & 0.2 & 1 & 1 & 1 & $4.638 \times 10^{-3}$ & 884 & 0.0190 & 25 & 3 & [72] \\
\hline Resin Tulsion A-27 & 1.1 & 0.833 & 1.1 & 1.724 & 1.90 & 1 & 1 & 1 & 50 & 5.5 & [30] \\
\hline Solid biodiesel waste residue & 9.61 & 6 & 0.531 & 1.02 & 0.542 & 2.404 & 4.642 & 26.83 & 30 & 2 & [73] \\
\hline Pediastrum boryanum & 7.69 & 4 & 0.329 & 2.73 & 0.898 & 0.581 & 748.8 & 252.8 & 25 & 2 & [26] \\
\hline Trewia nudiflora & 2.15 & 0.75 & 0.433 & 1.68 & 0.727 & 2.709 & 13.01 & 95.48 & 30 & 2 & [75] \\
\hline Alum-water treatment sludge & 0.001 & 10 & 0.027 & 0.564 & 0.0152 & 0.079 & 58.02 & 0.362 & 25 & 3 & [18] \\
\hline Polytetra-allylpropane diaminium & 1.92 & 0.7 & 2.612 & 18.80 & 49.10 & 0.0521 & 16.55 & 0.0449 & 20 & 6 & [53] \\
\hline Amine-magnetite nanoparticles & 0.096 & 1 & 0.123 & 3.6 & 0.443 & 0.543 & 6.24 & 1.840 & 25 & 3 & [2] \\
\hline Ustilago maydis & 0.48 & 10 & 1 & 1 & & 0.0375 & 42.74 & 0.0601 & 20 & 5.5 & [77] \\
\hline Amine silica magnetite & 2.88 & 1.07 & 0.631 & 19.92 & 12.57 & 2.497 & 205.3 & 1280 & Room & 2 & [57] \\
\hline Nano- $\gamma-\mathrm{Al}_{2} \mathrm{O}_{3}$ & 0.38 & 3 & 0.011 & 1.2 & 0.0132 & 0.156 & 93.6 & 2.278 & 25 & 3 & [78] \\
\hline Pteris vittata $\mathrm{L}$. & 1.92 & 1 & 1 & 1 & 1 & 1.479 & 3.12 & 6.825 & 30 & 2 & [59] \\
\hline Aspergillus niger & 0.96 & 10 & $8.32 \times 10^{-3}$ & 0.054 & $4.493 \times 10^{-4}$ & $8.30 \times 10^{-3}$ & 17,238 & 1.187 & 28 & 2.5 & [37] \\
\hline Palm kernel shell & 0.096 & 20 & 1 & 1 & 1 & 1 & $1.2 \times 10^{-5}$ & 1 & Room & 6 & [80] \\
\hline Bacterial cellulose/chitosan & & & 1 & 1 & 1 & 1 & 1 & 1 & 25 & 6 & [81] \\
\hline Kaolinite nanotubes & 1.92 & 0.333 & 1 & 1 & 1 & 1.074 & 4.802 & 5.534 & 30 & 2 & [82] \\
\hline Bacterial cellulose/attapulgite & 0.96 & 0.2 & 1.473 & 56.7 & 83.52 & 1.635 & $3.25 \times 10^{6}$ & $8.688 \times 10^{6}$ & 25 & 6 & [83] \\
\hline
\end{tabular}


The Weber-Morris equation [94] is a semi-empirical model often used in $\mathrm{Cr}(\mathrm{VI})$ sorption studies for evaluating whether the rate of the process is affected by solute diffusion within sorbent pores (intra-particle diffusion):

$$
q=k_{D} \sqrt{t}+\kappa
$$

Here $k_{D}$ is a kinetic diffusion parameter and $\kappa$ is a constant proportional to the thickness of the diffusion boundary layer. A linear correlation between $q$ and the root square of time suggests that the rate of $\mathrm{Cr}(\mathrm{VI})$ sorption is controlled by diffusion $[19,32,73]$. Some authors argued that the presence of multiple linear portions in the $q$ vs. $\sqrt{ } t$ plot indicates that the sorption process proceeds through two or more consecutive diffusive steps [75].

Another model used for modelling the sorption kinetic data is the Elovich equation [95], which envisages an exponential decrease of the sorption rate with an increase of bound sorbate $q$, without reaching equilibrium (for $t \rightarrow \infty, q \rightarrow \infty$ ):

$$
\frac{d q}{d t}=\alpha e^{-\beta q}
$$

where $\alpha$ is the initial $(t=0)$ sorption rate and $\beta$ indicates the extent to which the rate varies with $q$. It is agreed that the applicability of the Elovich model to experimental data provides evidence of heterogeneity of sorption sites [75]. Equation (36) can be integrated for the boundary conditions $t=0$ to $t=t$ and $q=0$ to $q=q$, yielding:

$$
q=\frac{1}{\beta} \ln (1+\alpha \beta t)
$$

Owing to historical difficulties (lack of computational power) associated with the application of non-linear curve fitting [96], an approximated-linearized form of Equation (37) was introduced by Chien and Clayton [97] for testing the applicability of the Elovich model. The approximated form of the integrated Elovich equation was derived on the assumption that for sufficiently high values of $t$, the term $\alpha \cdot \beta \cdot t$ becomes much greater than 1 so that Equation (37) reduces to:

$$
q=\frac{1}{\beta} \ln \alpha \beta+\ln t
$$

Thus, the validity of Equation (38) is verified by the linear plot of $q$ vs. $\ln t$. Although non-linear curve fitting is now easy to perform, linearization is still the first-choice procedure for testing the Elovich model, which may lead to incorrect interpretation of data. As a matter of fact, several recent studies of $\mathrm{Cr}(\mathrm{VI})$ sorption reported that the linearized Elovich equation (Equation (38)) gave less satisfactory fitting results than the PSO model $[4,19,75,82]$. However, as stated above, the exact integrated form for the Elovich equation (Equation (37)) ought to be employed for a rigorous comparison with the PSO model.

\section{Conclusions}

The primary mechanism of chromium sorption involves electrostatic interactions between the sorbate and the sorbent surface. The $\mathrm{pH}$ strongly affects chromium sorption behavior. The most frequently used models to describe the equilibrium of $\mathrm{Cr}(\mathrm{VI})$ sorption are the Langmuir model and the Freundlich model, the former usually providing better fitting results. The Pseudo First-Order and the Pseudo Second-Order model are the models of choice for the kinetics of $\mathrm{Cr}(\mathrm{VI})$ sorption. The Pseudo Second-Order model generally fits the data much better than the Pseudo First-Order model.

A critical survey shows that thermodynamic and kinetic analyses of $\mathrm{Cr}(\mathrm{VI})$ sorption reported in the recent literature are often incorrect. Common mistakes include miscalculation of the sorption equilibrium constant, erroneous extrapolation of data to standard conditions, and the application of regression models in linearized form. 
Author Contributions: Conceptualization, S.S.; data curation, P.I. and A.F.; writing-original draft preparation, A.F. and S.S.; writing-review and editing, S.C. and S.S.; supervision, D.M. and S.S. All authors have read and agreed to the published version of the manuscript.

Funding: This research has been supported by VALERE “VAnviteLli pEr la RicErca” PROGRAMME funded by the University of Campania "Luigi Vanvitelli".

Acknowledgments: The authors are grateful to Roberto Ligrone for very useful comments and suggestions.

Conflicts of Interest: The authors declare no conflict of interest.

\section{References}

1. Roy, P.K.; Swami, V.; Kumar, D.; Rajagopal, C. Removal of toxic metals using superabsorbent polyelectrolytic hydrogels. J. Appl. Polym. Sci. 2011, 122, 2415-2423. [CrossRef]

2. Norouzian Baghani, A.; Mahvi, A.H.; Gholami, M.; Rastkari, N.; Delikhoon, M. One-Pot synthesis, characterization and adsorption studies of amine-functionalized magnetite nanoparticles for removal of $\mathrm{Cr}$ (VI) and Ni (II) ions from aqueous solution: Kinetic, isotherm and thermodynamic studies. J. Environ. Health Sci. Eng. 2016, 14. [CrossRef]

3. Johnston, C.P.; Chrysochoou, M. Mechanisms of chromate adsorption on hematite. Geochim. Cosmochim. Acta 2014, 138, 146-157. [CrossRef]

4. Arris, S.; Bencheikh Lehocine, M.; Meniai, A.H. Sorption study of chromium sorption from wastewater using cereal by-products. Int. J. Hydrog. Energy 2016, 41, 10299-10310.

5. Kowalski, Z. Treatment of chromic tannery wastes. J. Hazard. Mater. 1994, 37, 137-141. [CrossRef]

6. Janoš, P.; Hůla, V.; Bradnová, P.; Pilařová, V.; Šedlbauer, J. Reduction and immobilization of hexavalent chromium with coal- and humate-based sorbents. Chemosphere 2009, 75, 732-738. [CrossRef] [PubMed]

7. Tran, H.V.; Tran, T.L.; Le, T.D.; Le, T.D.; Nguyen, H.M.T.; Dang, L.T. Graphene oxide enhanced adsorption capacity of chitosan/magnetite nanocomposite for $\mathrm{Cr}(\mathrm{VI})$ removal from aqueous solution. Mater. Res. Express 2019, 6, 025018. [CrossRef]

8. Mikhaylov, V.I.; Maslennikova, T.P.; Krivoshapkina, E.F.; Tropnikov, E.M.; Krivoshapkin, P.V. Express Al/Fe oxide-oxyhydroxide sorbent systems for $\mathrm{Cr}(\mathrm{VI})$ removal from aqueous solutions. Chem. Eng. J. 2018, 350, 344-355. [CrossRef]

9. Shi, X.; Dalal, N.S. On the hydroxyl radical formation in the reaction between hydrogen peroxide and biologically generated chromium(V) species. Arch. Biochem. Biophys. 1990, 277, 342-350. [CrossRef]

10. Bagbi, Y.; Sarswat, A.; Mohan, D.; Pandey, A.; Solanki, P.R. Lead and Chromium Adsorption from Water using L-Cysteine Functionalized Magnetite (Fe3O4) Nanoparticles. Sci. Rep. 2017, 7. [CrossRef]

11. Huang, C.P.; Wu, M.H. Chromium removal by carbon adsorption. J. Water Pollut. Control Fed. 1975, 47, 2437-2446.

12. Huang, C.P.; Wu, M.H. The removal of chromium(VI) from dilute aqueous solution by activated carbon. Water Res. 1977, 11, 673-679. [CrossRef]

13. Hamadi, N.K.; Chen, X.D.; Farid, M.M.; Lu, M.G.Q. Adsorption kinetics for the removal of chromium(VI) from aqueous solution by adsorbents derived from used tyres and sawdust. Chem. Eng. J. 2001, 84, 95-105. [CrossRef]

14. Khan, S.A.; Riaz-ur-Rehman Khan, M.A. Adsorption of chromium (III), chromium (VI) and silver (I) on bentonite. Waste Manag. 1995, 15, 271-282. [CrossRef]

15. Sharma, D.C.; Forster, C.F. A preliminary examination into the adsorption of hexavalent chromium using low-cost adsorbents. Bioresour. Technol. 1994, 47, 257-264. [CrossRef]

16. Sharma, D.C.; Forster, C.F. Removal of hexavalent chromium using sphagnum moss peat. Water Res. 1993, 27, 1201-1208. [CrossRef]

17. Salvestrini, S.; Vanore, P.; Bogush, A.; Mayadevi, S.; Campos, L.C. Sorption of metaldehyde using granular activated carbon. J. Water Reuse Desalin. 2017, 7, 280-287. [CrossRef]

18. Zhou, Y.F.; Haynes, R.J. Removal of $\mathrm{Pb}(\mathrm{II}), \mathrm{Cr}(\mathrm{III})$ and $\mathrm{Cr}(\mathrm{VI})$ from aqueous solutions using alum-derived water treatment sludge. Water. Air. Soil Pollut. 2011, 215, 631-643. [CrossRef]

19. Javadian, H.; Ahmadi, M.; Ghiasvand, M.; Kahrizi, S.; Katal, R. Removal of Cr(VI) by modified brown algae Sargassum bevanom from aqueous solution and industrial wastewater. J. Taiwan Inst. Chem. Eng. 2013, 44, 977-989. [CrossRef] 
20. Shi, T.; Wang, Z.; Liu, Y.; Jia, S.; Changming, D. Removal of hexavalent chromium from aqueous solutions by D301, D314 and D354 anion-exchange resins. J. Hazard. Mater. 2009, 161, 900-906. [CrossRef]

21. Das, S.K.; Guha, A.K. Biosorption of hexavalent chromium by Termitomyces clypeatus biomass: Kinetics and transmission electron microscopic study. J. Hazard. Mater. 2009, 167, 685-691. [CrossRef] [PubMed]

22. Kantar, C.; Ari, C.; Keskin, S.; Dogaroglu, Z.G.; Karadeniz, A.; Alten, A. Cr(VI) removal from aqueous systems using pyrite as the reducing agent: Batch, spectroscopic and column experiments. J. Contam. Hydrol. 2015, 174, 28-38. [CrossRef] [PubMed]

23. Gherasim, C.V.; Bourceanu, G.; Olariu, R.I.; Arsene, C. A novel polymer inclusion membrane applied in chromium (VI) separation from aqueous solutions. J. Hazard. Mater. 2011, 197, 244-253. [CrossRef]

24. Gheju, M.; Balcu, I.; Mosoarca, G. Removal of Cr(VI) from aqueous solutions by adsorption on MnO2. J. Hazard. Mater. 2016, 310, 270-277. [CrossRef] [PubMed]

25. Kyzas, G.Z.; Kostoglou, M.; Lazaridis, N.K. Copper and chromium(VI) removal by chitosan derivatives-Equilibrium and kinetic studies. Chem. Eng. J. 2009, 152, 440-448. [CrossRef]

26. Ozer, T.B.; Erkaya, I.A.; Udoh, A.U.; Duygu, D.Y.; Akbulut, A.; Bayramoglu, G.; Arica, M.Y. Biosorption of $\mathrm{Cr}(\mathrm{VI})$ by free and immobilized Pediastrum boryanum biomass: Equilibrium, kinetic, and thermodynamic studies. Environ. Sci. Pollut. Res. 2012, 19, 2983-2993. [CrossRef]

27. Cui, Y.; Masud, A.; Aich, N.; Atkinson, J.D. Phenol and Cr(VI) removal using materials derived from harmful algal bloom biomass: Characterization and performance assessment for a biosorbent, a porous carbon, and Fe/C composites. J. Hazard. Mater. 2019, 368, 477-486. [CrossRef]

28. Campos, V. The sorption of toxic elements onto natural zeolite, synthetic goethite and modified powdered block carbon. Environ. Earth Sci. 2009, 59, 737-744. [CrossRef]

29. Di Natale, F.; Erto, A.; Lancia, A.; Musmarra, D. Equilibrium and dynamic study on hexavalent chromium adsorption onto activated carbon. J. Hazard. Mater. 2015, 281, 47-55. [CrossRef]

30. Koujalagi, P.S.; Divekar, S.V.; Kulkarni, R.M.; Nagarale, R.K. Kinetics, thermodynamic, and adsorption studies on removal of chromium(VI) using Tulsion A-27(MP) resin. Desalin. Water Treat. 2013, 51, 3273-3283. [CrossRef]

31. Chakravarty, R.; Khan, M.M.R.; Das, A.R.; Guha, A.K. Biosorptive removal of chromium by husk of Lathyrus sativus: Evaluation of the binding mechanism, kinetic and equilibrium study. Eng. Life Sci. 2013, 13, 312-322. [CrossRef]

32. Wu, S.; Hu, J.; Wei, L.; Du, Y.; Shi, X.; Deng, H.; Zhang, L. Construction of porous chitosan-xylan-TiO2 hybrid with highly efficient sorption capability on heavy metals. J. Environ. Chem. Eng. 2014, 2, 1568-1577. [CrossRef]

33. Salvestrini, S.; Sagliano, P.; Iovino, P.; Capasso, S.; Colella, C. Atrazine adsorption by acid-activated zeolite-rich tuffs. Appl. Clay Sci. 2010, 49, 330-335. [CrossRef]

34. González, P.S.; Ambrosio, L.F.; Paisio, C.E.; Talano, M.A.; Medina, M.I.; Agostini, E. Chromium (VI) remediation by a native strain: Effect of environmental conditions and removal mechanisms involved. Environ. Sci. Pollut. Res. 2014, 21, 13551-13559. [CrossRef]

35. Khitous, M.; Salem, Z.; Halliche, D. Effect of interlayer anions on chromium removal using Mg-Al layered double hydroxides: Kinetic, equilibrium and thermodynamic studies. Chin. J. Chem. Eng. 2016, 24, 433-445. [CrossRef]

36. Mahmoud, M.E.; Yakout, A.A.; Abdel-Aal, H.; Osman, M.M. Speciation and selective biosorption of Cr(III) and $\mathrm{Cr}(\mathrm{VI})$ using nanosilica immobilized-fungi biosorbents. J. Environ. Eng. 2015, 141. [CrossRef]

37. Do Vale, M.S.; do Nascimento, R.F.; Leitão, R.C.; Santaella, S.T. Cr and Zn biosorption by Aspergillus niger. Environ. Earth Sci. 2016, 75. [CrossRef]

38. Hans, R.; Senanayake, G.; Dharmasiri, L.C.S.; Mathes, J.A.P.; Kim, D.J. A preliminary batch study of sorption kinetics of $\mathrm{Cr}(\mathrm{VI})$ ions from aqueous solutions by a magnetic ion exchange (MIEX $\left.{ }^{\circledR}\right)$ resin and determination of film/pore diffusivity. Hydrometallurgy 2016, 164, 208-218. [CrossRef]

39. Bibi, I.; Niazi, N.K.; Choppala, G.; Burton, E.D. Chromium(VI) removal by siderite $\left(\mathrm{FeCO}_{3}\right)$ in anoxic aqueous solutions: An X-ray absorption spectroscopy investigation. Sci. Total Environ. 2018, 640-641, 1424-1431. [CrossRef]

40. Zhang, Z.; Guo, G.; Li, X.; Zhao, Q.; Bi, X.; Wu, K.; Chen, H. Effects of hydrogen-peroxide supply rate on schwertmannite microstructure and chromium(VI) adsorption performance. J. Hazard. Mater. 2019, 367, 520-528. [CrossRef] 
41. Zhang, S.; Lyu, H.; Tang, J.; Song, B.; Zhen, M.; Liu, X. A novel biochar supported CMC stabilized nano zero-valent iron composite for hexavalent chromium removal from water. Chemosphere 2019, 217, 686-694. [CrossRef] [PubMed]

42. Erto, A.; Andreozzi, R.; Di Natale, F.; Lancia, A.; Musmarra, D. Experimental and isotherm-models analysis on TCE and PCE adsorption onto activated carbon. Chem. Eng. Trans. 2009, 17, 293-298. [CrossRef]

43. Di Natale, F.; Lancia, A.; Molino, A.; Musmarra, D. Removal of chromium ions form aqueous solutions by adsorption on activated carbon and char. J. Hazard. Mater. 2007, 145, 381-390. [CrossRef]

44. Langmuir, I. The adsorption of gases on plane surfaces of glass, mica and platinum. J. Am. Chem. Soc. 1918, 40, 1361-1403. [CrossRef]

45. Salvestrini, S. Analysis of the Langmuir rate equation in its differential and integrated form for adsorption processes and a comparison with the pseudo first and pseudo second order models. React. Kinet. Mech. Catal. 2018, 123, 455-472. [CrossRef]

46. Salvestrini, S. A modification of the Langmuir rate equation for diffusion-controlled adsorption kinetics. React. Kinet. Mech. Catal. 2019, 128, 571-586. [CrossRef]

47. Freundlich, H. Über die Adsorption in Lösungen. Z. Phys. Chem. 2017, 57, 385-470. [CrossRef]

48. Paul, M.L.; Samuel, J.; Chandrasekaran, N.; Mukherjee, A. Comparative kinetics, equilibrium, thermodynamic and mechanistic studies on biosorption of hexavalent chromium by live and heat killed biomass of Acinetobacter junii VITSUKMW2, an indigenous chromite mine isolate. Chem. Eng. J. 2012, 187, 104-113. [CrossRef]

49. Jain, M.; Yadav, M.; Kohout, T.; Lahtinen, M.; Garg, V.K.; Sillanpää, M. Development of iron oxide/activated carbon nanoparticle composite for the removal of $\mathrm{Cr}(\mathrm{VI}), \mathrm{Cu}(\mathrm{II})$ and $\mathrm{Cd}(\mathrm{II})$ ions from aqueous solution. Water Resour. Ind. 2018, 20, 54-74. [CrossRef]

50. Kim, E.J.; Park, S.; Hong, H.J.; Choi, Y.E.; Yang, J.W. Biosorption of chromium (Cr(III)/Cr(VI)) on the residual microalga Nannochloris oculata after lipid extraction for biodiesel production. Bioresour. Technol. 2011, 102, 11155-11160. [CrossRef]

51. Albadarin, A.B.; Mangwandi, C.; Al-Muhtaseb, A.H.; Walker, G.M.; Allen, S.J.; Ahmad, M.N.M. Kinetic and thermodynamics of chromium ions adsorption onto low-cost dolomite adsorbent. Chem. Eng. J. 2012, 179, 193-202. [CrossRef]

52. Sirusbakht, S.; Vafajoo, L.; Soltani, S.; Habibi, S. Sawdust bio sorption of chromium (VI) ions from aqueous solutions. Chem. Eng. Trans. 2018, 70, 1147-1152. [CrossRef]

53. Liu, L.; Yang, Z.; Zhao, L.; Liu, J.; Liu, X.; Xue, J.; Tang, A. Removal performance and mechanism of poly(N1,N1,N3,N3-tetraallylpropane-1,3-diaminium chloride) toward $\mathrm{Cr}(\mathrm{VI})$. Environ. Technol. 2020, 41, 2450-2463. [CrossRef] [PubMed]

54. Anandaraj, B.; Eswaramoorthi, S.; Rajesh, T.P.; Aravind, J.; Suresh Babu, P. Chromium(VI) adsorption by Codium tomentosum: Evidence for adsorption by porous media from sigmoidal dose-response curve. Int. J. Environ. Sci. Technol. 2018, 15, 2595-2606. [CrossRef]

55. Sutkowy, M.; Klosowski, G. Use of the coenobial green algae Pseudopediastrum boryanum (Chlorophyceae) to remove hexavalent chromium from contaminated aquatic ecosystems and industrialwastewaters. Water 2018, 10, 712. [CrossRef]

56. Jemima, W.S.; Magesan, P.; Chiranjeevi, P.; Umapathy, M.J. Sorption Properties of Organo Modified Montmorillonite Clay for the Reclamation of Chromium (VI) from Waste Water. Silicon 2019, 11, 925-933. [CrossRef]

57. Shariati, S.; Khabazipour, M.; Safa, F. Synthesis and application of amine functionalized silica mesoporous magnetite nanoparticles for removal of chromium(VI) from aqueous solutions. J. Porous Mater. 2017, 24, 129-139. [CrossRef]

58. Kumar, R.; Kim, S.J.; Kim, K.H.; Lee, S.H.; Park, H.S.; Jeon, B.H. Removal of hazardous hexavalent chromium from aqueous phase using zirconium oxide-immobilized alginate beads. Appl. Geochem. 2018, 88, 113-121. [CrossRef]

59. Prabhu, S.G.; Srinikethan, G.; Hegde, S. Spontaneous Cr(VI) and Cd(II) biosorption potential of native pinnae tissue of Pteris vittata L., a tropical invasive pteridophyte. Int. J. Phytoremediat. 2019, 21, 380-390. [CrossRef] [PubMed]

60. Sun, X.F.; Liu, C.; Ma, Y.; Wang, S.G.; Gao, B.Y.; Li, X.M. Enhanced Cu(II) and Cr(VI) biosorption capacity on poly(ethylenimine) grafted aerobic granular sludge. Colloids Surf. B Biointerfaces 2011, 82, 456-462. [CrossRef] 
61. Sips, R. On the structure of a catalyst surface. II. J. Chem. Phys. 1950, 18, 1024-1026. [CrossRef]

62. Setshedi, K.Z.; Bhaumik, M.; Onyango, M.S.; Maity, A. High-performance towards Cr(VI) removal using multi-active sites of polypyrrole-graphene oxide nanocomposites: Batch and column studies. Chem. Eng. J. 2015, 262, 921-931. [CrossRef]

63. Dragan, E.S.; Humelnicu, D.; Dinu, M.V.; Olariu, R.I. Kinetics, equilibrium modeling, and thermodynamics on removal of $\mathrm{Cr}(\mathrm{VI})$ ions from aqueous solution using novel composites with strong base anion exchanger microspheres embedded into chitosan/poly(vinyl amine) cryogels. Chem. Eng. J. 2017, 330, 675-691. [CrossRef]

64. Karthik, R.; Meenakshi, S. Facile synthesis of cross linked-chitosan-grafted-polyaniline composite and its Cr(VI) uptake studies. Int. J. Biol. Macromol. 2014, 67, 210-219. [CrossRef] [PubMed]

65. Dudek, B.; Kuśtrowski, P.; Bialas, A.; Natkanśki, P.; Piwowarska, Z.; Chmielarz, L.; Kozak, M.; Michalik, M. Influence of textural and structural properties of $\mathrm{Mg} \mathrm{Al}$ and $\mathrm{Mg} \mathrm{Zn} \mathrm{Al} \mathrm{containing} \mathrm{hydrotalcite} \mathrm{derived} \mathrm{oxides}$ on $\mathrm{Cr}(\mathrm{VI})$ adsorption capacity. Mater. Chem. Phys. 2012, 132, 929-936. [CrossRef]

66. Lv, G.; Li, Z.; Jiang, W.T.; Ackley, C.; Fenske, N.; Demarco, N. Removal of Cr(VI) from water using Fe(II)-modified natural zeolite. Chem. Eng. Res. Des. 2014, 92, 384-390. [CrossRef]

67. Mikhaylov, V.I.; Maslennikova, T.P.; Ugolkov, V.L.; Krivoshapkin, P.V. Hydrothermal synthesis, characterization and sorption properties of $\mathrm{Al} / \mathrm{Fe}$ oxide-oxyhydroxide composite powders. Adv. Powder Technol. 2016, 27, 756-764. [CrossRef]

68. Song, W.; Gao, B.; Zhang, T.; Xu, X.; Huang, X.; Yu, H.; Yue, Q. High-capacity adsorption of dissolved hexavalent chromium using amine-functionalized magnetic corn stalk composites. Bioresour. Technol. 2015, 190, 550-557. [CrossRef]

69. Sreenivas, K.M.; Inarkar, M.B.; Gokhale, S.V.; Lele, S.S. Re-utilization of ash gourd (Benincasa hispida) peel waste for chromium (VI) biosorption: Equilibrium and column studies. J. Environ. Chem. Eng. 2014, 2, 455-462. [CrossRef]

70. Wassie, A.B.; Srivastava, V.C. Teff straw characterization and utilization for chromium removal from wastewater: Kinetics, isotherm and thermodynamic modelling. J. Environ. Chem. Eng. 2016, 4, 1117-1125. [CrossRef]

71. Arcos-Casarrubias, J.A.; Cruz-Díaz, M.R.; Cardoso-Martínez, J.; Vázquez-Arenas, J.; Caballero-Domínguez, F.V. Chromium adsorption into a macroporous resin based on vinylpyridine-divinylbenzene copolymers: Thermodynamics, kinetics, and process dynamic in a fixed bed column. Adsorption 2018, 24, 105-120. [CrossRef]

72. Badruddoza, A.Z.M.; Bhattarai, B.; Suri, R.P.S. Environmentally Friendly $\beta$-Cyclodextrin-Ionic Liquid Polyurethane-Modified Magnetic Sorbent for the Removal of PFOA, PFOS, and Cr(VI) from Water. ACS Sustain. Chem. Eng. 2017, 5, 9223-9232. [CrossRef]

73. Muthusamy, S.; Venkatachalam, S.; Jeevamani, P.M.K.; Rajarathinam, N. Biosorption of Cr(VI) and Zn(II) ions from aqueous solution onto the solid biodiesel waste residue: Mechanistic, kinetic and thermodynamic studies. Environ. Sci. Pollut. Res. 2014, 21, 593-608. [CrossRef]

74. Olguín, M.T.; López-González, H.; Serrano-Gómez, J. Hexavalent chromium removal from aqueous solutions by Fe-modified peanut husk. Water. Air. Soil Pollut. 2013, 224. [CrossRef]

75. Bhattacharya, P.; Banerjee, P.; Mallick, K.; Ghosh, S.; Majumdar, S.; Mukhopadhyay, A.; Bandyopadhyay, S. Potential of biosorbent developed from fruit peel of Trewia nudiflora for removal of hexavalent chromium from synthetic and industrial effluent: Analyzing phytotoxicity in germinating Vigna seeds. J. Environ. Sci. Health Part A Toxic/Hazard. Subst. Environ. Eng. 2013, 48, 706-719. [CrossRef]

76. Rapti, S.; Sarma, D.; Diamantis, S.A.; Skliri, E.; Armatas, G.S.; Tsipis, A.C.; Hassan, Y.S.; Alkordi, M.; Malliakas, C.D.; Kanatzidis, M.G.; et al. All in one porous material: Exceptional sorption and selective sensing of hexavalent chromium by using a $\mathrm{Zr}^{4+}$ MOF. J. Mater. Chem. A 2017, 5, 14707-14719. [CrossRef]

77. Serrano-Gómez, J.; Olguín, M.T. Separation of $\mathrm{Cr}(\mathrm{VI})$ from aqueous solutions by adsorption on the microfungus Ustilago maydis. Int. J. Environ. Sci. Technol. 2015, 12, 2559-2566. [CrossRef]

78. Shokati Poursani, A.; Nilchi, A.; Hassani, A.H.; Shariat, M.; Nouri, J. A novel method for synthesis of nano- $\gamma-\mathrm{Al}_{2} \mathrm{O}_{3}$ : Study of adsorption behavior of chromium, nickel, cadmium and lead ions. Int. J. Environ. Sci. Technol. 2015, 12, 2003-2014. [CrossRef]

79. Zhang, F.; Du, N.; Li, H.; Song, S.; Hou, W. Sorbent effect on the sorption of Cr(VI) on a Mg6AlFe-layered double hydroxide and its calcined product in aqueous solutions. Colloid Polym. Sci. 2015, 293, 1961-1969. [CrossRef] 
80. Baby, R.; Saifullah, B.; Hussein, M.Z. Palm Kernel Shell as an effective adsorbent for the treatment of heavy metal contaminated water. Sci. Rep. 2019, 9. [CrossRef] [PubMed]

81. Li, D.; Tian, X.; Wang, Z.; Guan, Z.; Li, X.; Qiao, H.; Ke, H.; Luo, L.; Wei, Q. Multifunctional adsorbent based on metal-organic framework modified bacterial cellulose/chitosan composite aerogel for high efficient removal of heavy metal ion and organic pollutant. Chem. Eng. J. 2020, 383. [CrossRef]

82. Abukhadra, M.R.; Bakry, B.M.; Adlii, A.; Yakout, S.M.; El-Zaidy, M.A. Facile conversion of kaolinite into clay nanotubes (KNTs) of enhanced adsorption properties for toxic heavy metals $\left(\mathrm{Zn}^{2+}, \mathrm{Cd}^{2+}, \mathrm{Pb}^{2+}\right.$, and $\left.\mathrm{Cr}^{6+}\right)$ from water. J. Hazard. Mater. 2019, 374, 296-308. [CrossRef] [PubMed]

83. Chen, X.; Cui, J.; Xu, X.; Sun, B.; Zhang, L.; Dong, W.; Chen, C.; Sun, D. Bacterial cellulose/attapulgite magnetic composites as an efficient adsorbent for heavy metal ions and dye treatment. Carbohydr. Polym. 2020, 229. [CrossRef]

84. Atkins, P.; de Paula, J.; Keeler, J. Atkins' Physical Chemistry; OUP Oxford: Oxford, UK, 2017; ISBN 978-0198769866.

85. Fenti, A.; Iovino, P.; Salvestrini, S. Some remarks on "A critical review of the estimation of the thermodynamic parameters on adsorption equilibria. Wrong use of equilibrium constant in the Van't Hoof equation for calculation of thermodynamic parameters of adsorption". J. Mol. Liq. 2019, 276, 529-530. [CrossRef]

86. Khan, A.A.; Singh, R.P. Adsorption thermodynamics of carbofuran on $\mathrm{Sn}$ (IV) arsenosilicate in $\mathrm{H}^{+}, \mathrm{Na}^{+}$and $\mathrm{Ca}^{2+}$ forms. Colloids Surf. 1987, 24, 33-42. [CrossRef]

87. Chianese, S.; Fenti, A.; Iovino, P.; Musmarra, D.; Salvestrini, S. Sorption of organic pollutants by humic acids: A review. Molecules 2020, 25, 918. [CrossRef]

88. Salvestrini, S.; Leone, V.; Iovino, P.; Canzano, S.; Capasso, S. Considerations about the correct evaluation of sorption thermodynamic parameters from equilibrium isotherms. J. Chem. Thermodyn. 2014, 68, 310-316. [CrossRef]

89. Salvestrini, S.; Fenti, A.; Chianese, S.; Iovino, P.; Musmarra, D. Diclofenac sorption from synthetic water: Kinetic and thermodynamic analysis. J. Environ. Chem. Eng. 2020, 8, 104105. [CrossRef]

90. Canzano, S.; Iovino, P.; Salvestrini, S.; Capasso, S. Comment on "Removal of anionic dye Congo red from aqueous solution by raw pine and acid-treated pine cone powder as adsorbent: Equilibrium, thermodynamic, kinetics, mechanism and process design". Water Res. 2012, 46, 4314-4315. [CrossRef]

91. Lagergren, S.K. About the theory of so-called adsorption of soluble substances, Kungliga Svenska Vetenskapsakademiens. Handl. Band 1898, 24, 1.

92. Ho, Y.S.; McKay, G. Pseudo-second order model for sorption processes. Process Biochem. 1999, 34, 451-465. [CrossRef]

93. Canzano, S.; Iovino, P.; Leone, V.; Salvestrini, S.; Capasso, S. Use and misuse of sorption kinetic data: A common mistake that should be avoided. Adsorpt. Sci. Technol. 2012, 30, 217-225. [CrossRef]

94. Weber, W. Kinetics of Adsorption on Carbon from Solution. J. Sanit. Eng. Div. 1963, 89, 31-60.

95. Low, M.J.D. Kinetics of chemisorption of gases on solids. Chem. Rev. 1960, 60, 267-312. [CrossRef]

96. Lente, G. Deterministic Kinetics in Chemistry and Systems Biology: The Dynamics of Complex Reaction Networks; Springer Briefs in Molecular Science; Springer International Publishing: Cham, Switzerland, 2015; ISBN 3319154826.

97. Chien, S.H.; Clayton, W.R. Application of Elovich Equation to the Kinetics of Phosphate Release and Sorption in Soils. Soil Sci. Soc. Am. J. 1980, 44, 265-268. [CrossRef]

(C) 2020 by the authors. Licensee MDPI, Basel, Switzerland. This article is an open access article distributed under the terms and conditions of the Creative Commons Attribution (CC BY) license (http://creativecommons.org/licenses/by/4.0/). 